\title{
Queer Kids: A Comprehensive Annotated Legal Bibliography on Lesbian, Gay, Bisexual, Transgender, and Questioning Youth
}

\author{
Sarah E. Valentine ${ }^{\dagger}$
}

\begin{abstract}
This Bibliography is a comprehensive collection of law review articles, and selected other materials, relevant to lesbian, gay, bisexual, transgendered, and questioning youth. These "queer kids"-minors between the ages of ten and twenty who are perceived as being gender or sexuality nonconforming-are the most endangered and underserved adolescent population in the United States. They face danger in their homes, schools, and the juvenile justice system. Their ability to protect themselves is compromised by discrimination and by their status as minors. Intended as a resource for scholars, policymakers, and practitioners, this bibliography collects, discusses, and organizes legal scholarship, selected reports and studies, and influential personal narratives from queer kids.
\end{abstract}

† Legal Research Coordinator, Associate Law Library Professor, City University of New York (CUNY) School of Law. I formerly represented juveniles in New York Family Court, and also worked in a general legal services practice. I wish to thank Julie Lim, Director, CUNY School of Law Library, and Camille Broussard, Deputy Librarian, New York Law School Library, for their support and encouragement. In addition, this bibliography would not have been compiled without the support, encouragement, and assistance of Ruthann Robson. A portion of this bibliography was presented at a panel on Queer Kids and the Law at an annual meeting of the American Association of Law Librarians. 


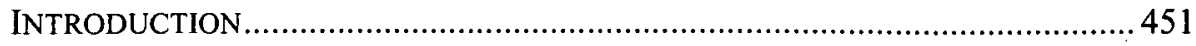

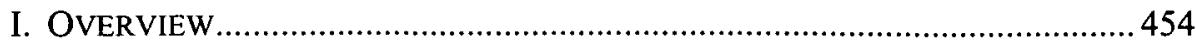

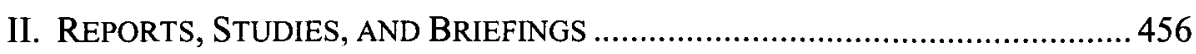

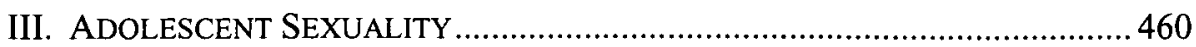

IV. TRANSGENDERED YOUTH AND THE USE OF GENDER IDENTITY

DISORDER (GID) TO TARGET GENDER-NONCONFORMING YOUTH..... 463

V. INSTITUTIONALIZATION AND CONVERSION OR REPARATIVE THERAPY ....468

VI. FOSTER CARE AND THE JUVENILE JUSTICE SYSTEM .................................47 47

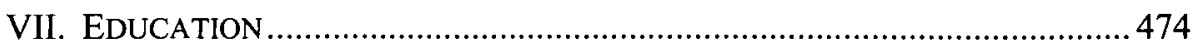

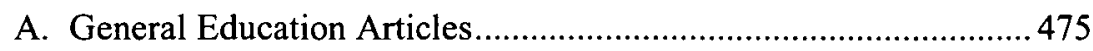

B. Addressing Violence in the School Setting: Bullying and Harassment of Queer Youth...........................................................476

C. Freedom of Speech and Other Constitutional Issues Affecting

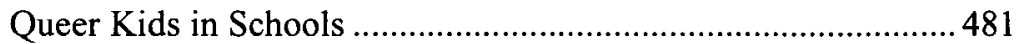

D. Gay/Straight Alliances and Other Queer Student Groups .............. 482

E. The Harvey Milk School and Other Schools Designed Specifically for Queer Students ..................................................485

F. Canadian Articles Addressing Queer Student Issues ..................... 487

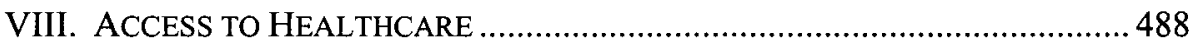

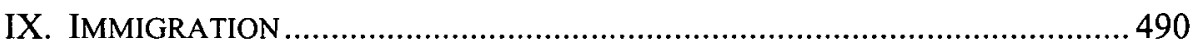

Additional Immigration Articles ....................................................492

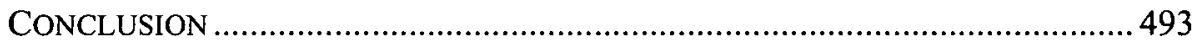




\section{INTRODUCTION}

Queer kids are the most isolated, attacked, endangered, and underserved adolescent population in the United States. Their sexuality is often a wedge that separates them from their families, schools, and peers. ${ }^{1}$ Perceptions of queerness make these kids a target at home, in school, and on the streets. ${ }^{2}$ Government agencies whose stated goals are protecting and assisting children are often more dangerous to queer youth than living on the streets. ${ }^{3}$ Queer kids are frequently institutionalized or placed in private treatment programs because of their gender nonconformity or their perceived sexuality. ${ }^{4}$ The involuntary "treatments" to cure these youth are unregulated, psychologically suspect, and often quite literally "shocking.",

1. See Rita Lee, Health Care Problems of Lesbian, Gay, Bisexual and Transgender Patients, 172 W.J. MED. 403, 404 (2000) (citing studies finding that more than 95\% of lesbian, gay, bisexual, and transgender youth feel separated and emotionally isolated from their peers because they feel different); see also BENNETT L. SINGER \& DAVID DESCHAMPS, GAY AND LESBIAN STATS: A POCKET GUIDE OF FACTS AND FIGURES (1994) (noting that one in four queer youth are forced to leave home due to conflict with families). According to the 2005 National School Climate Survey of the Gay, Lesbian and Straight Education Network (GLSEN), 64\% of LGBT students felt unsafe in their schools, GAY, LESBIAN \& Straight Education Network, THE 2005 NATIONAL SChoOl Climate SuRvey, available at http://www.glsen.org/binary-data/GLSEN_ATTACHMENTS/ file/585-1.pdf; according to GLSEN's 2001 Climate Survey, $89 \%$ of transgender students felt unsafe in school. GAY, LESBIAN \& STRAIGHT EdUCATION NETWORK, THE 2001 NATIONAL SCHOOL ClimATE SURVEY, available at http://www.glsen.org/binary-data/GLSEN_ATTACHMENTS/file/185-1.pdf.

2. See Gay, Lesbian and Straight Education Network, From teasing to Torment: SCHOOL CLIMATE IN AMERICA 80 (2005), available at http:/www.glsen.org/binarydata/GLSEN_ATTACHMENTS/file/499-1.pdf (noting that $90 \%$ of all queer teens indicate that they have been verbally or physically harassed during the past year); NICHOLAS RAY, NATIONAL GAY AND LESBIAN TASK FORCE POLICY INSTITUTE \& NATIONAL COALITION FOR THE HOMELESS, LESBIAN, GAY, BISEXUAL AND TRANSGENDER YOUTH: AN EPIDEMIC OF HoMElEsSness 3 (2006), http://www.thetaskforce.org/reports_and_research/Homeless_Youth (noting that queer youth are more than seven times as likely to be victims of a crime); Lee, supra note 1, at 404 (citing studies finding that "[a]lmost half of gay youth and twenty percent of lesbians are verbally or physically assaulted in secondary school" and that queer youth are four times more likely to be threatened with a weapon on school grounds than their non-queer peers); see also Kim Paula Kirkley, Don't Forget the Safety Net that All-Gay Schools Provide in Considering the Issues Raised by All-Female Public Education, 14 N.Y.L. SCH. J. HUM. RTS. 127 (1997) (discussing severe beatings, rapes, and attempted murders of queer youth by their peers).

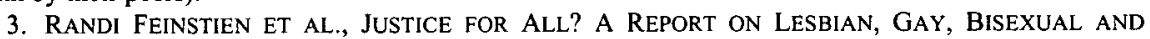
TRANSGENDERED YOUTH IN THE NEW YORK JUVENILE JUSTICE SYSTEM 15-16 (2001), available at http://www.urbanjustice.org/pdf/publications/lesbianandgay/justiceforallreport.pdf (documenting the horrific treatment faced by queer kids in foster care).

4. Queer youth are particularly vulnerable to institutionalization because of normal adolescent confusion in coming to terms with their sexual orientation. Samuel M. Leaf, How Voluntary is the Voluntary Commitment of Minors? Disparities in the Treatment of Children and Adults Under New York's Civil Commitment Law, 62 BROOK. L. REv. 1687, 1719-20 (1996).

5. Lyn Duff, I Was a Teenage Test Case, 16 CAL. LAw. 47 (1996); Thomas Mournian, Hiding Out, S.F. BAY GUARDIAN, Apr. 8, 1998, at 23. Both articles describe locked facilities where reparative or conversion therapy includes: unrelenting counseling that homosexuality is abnormal, immoral, or unhealthy; hypnosis; aggressive prescription of psychotropic medications; strip-searching; the use of isolation cells; and other behavior modification techniques. Mournian's article describes the use of penile plesthymographs (the application of electrodes to genitals to test arousal). 
In the past twenty-five years, a slow but growing recognition of the plight of queer youth has emerged among educators, social workers, social scientists, and finally the legal profession. ${ }^{6}$ Established organizations such as the National Center for Lesbian Rights (NCLR), Lambda Legal Defense Fund (Lambda Legal), the Urban Justice Center, the Child Welfare League of America (CWA), the National Gay and Lesbian Task Force (NGLTF), Human Rights Watch, and the ACLU have begun to focus on the plight of queer adolescents. In addition, newer organizations have formed, such as the Gay, Lesbian and Straight Education Network (GLSEN) and the Hetrick-Martin Institute, whose main focus is queer youth.

Since the mid-1980s, studies have been funded, articles published, lawsuits brought, schools started, policy reform undertaken, and public education pursued, all with the intent of bettering the situation of queer kids. In many ways queer youth have also begun to take an active part in the fight against society's failure to treat them with the dignity and respect they deserve. Queer runaways care for each other on the streets; queer students demand gay/straight alliances in schools; and queer youth establish websites and web forums and seek out legal representation to redress physical and mental abuse. ${ }^{7}$ Still, while gains have been made, queer youth continue to face horrendous obstacles. ${ }^{8}$

This annotated Bibliography collects and presents primarily legal sources that illuminate both the problems faced by queer youth and potential legal solutions to those problems. It is intended to assist practitioners, policymakers, and scholars working on issues affecting queer youth. Because it is not uncommon for queer kids to face multiple legal obstacles based on their perceived "queerness," I have attempted to be as comprehensive as possible in collecting works that address these issues. Generally, I have not included works

6. Education and Urban Society devoted its May 2000 issue to the "role that schools play in the creation and perpetuation of discrimination toward LGBTQ students in America's schools." Ian K. Macgillivray \& Genét Kozik-Rosabal, Introduction, 32 EDUC. \& URB. SOC'Y 287 (2000). The March/April 2006 edition of Child Welfare was dedicated to the issue of "LGBTQ Youth in Child Welfare," paying particular attention to queer kids in the foster care and juvenile justice systems. Gerald P. Mallon \& Rob Woronoff, Busting Out of the Child Welfare Closet: Lesbian, Gay, Bisexual, and Transgender Affirming Approaches to Child Welfare, 85 CHILD WELFARE 115-16 (2006). The Journal of Gay and Lesbian Issues in Education has changed its name to the Journal of LGBT Youth to "better reflect a youth focus." Press Release, Haworth Press, Newly Retitled Haworth Press Joumal Soon off the Press: Journal of LGBT Youth. (Aug. 24, 2007) (on file with author). See also RITCH C. SAVINWilliams, THE NEW GAY TEENAGER $49-67$ (2005) (noting a growing awareness of gay teens in the 1970 s, and tracking the attention paid to this age cohort through the present). In October 2007, the governor of Califomia signed the Juvenile Justice Safety and Protection Act, which specifically prohibits discrimination or harassment of incarcerated youth on the basis of actual or perceived "sexual orientation," "gender identity," or "HIV status." 2007 Cal. Legis. Serv. ch. 649 (West).

7. See Mournian, supra note 5 (describing the San Francisco network of "safe houses" that shelter queer youth, many of whom escaped and/or helped others escape from institutions, mental hospitals, and treatment centers where they were placed by their parents). In addition, queer youth are the force behind the Gay/Straight Alliance groups in schools and the organization of the National Day of Silence. There are multiple youth-run websites providing information and informal peer support and there are both national and local queer youth-run support groups around the country.

8. See infra Part II. 
aimed at a non-legal or non-scholarly audience such as those written for teens explaining their legal rights. Likewise, individual social science works are not included as annotations. These studies are easily found in the footnotes of the articles and reports below and are so numerous as to be beyond the scope of this compilation.

For this Bibliography "queer kids" are minors occupying that nether world of adolescence-falling somewhere between the ages of ten and twenty ${ }^{9}$ - who are, who may be, who are questioning whether or not they are, who may be seen as being, or who are targeted for being lesbian, gay, bisexual, transgender, or gender nonconforming. They can face every sort of legal or non-legal problem that a queer adult may face while operating under the distinct handicap of their age. Being seen as children in the eyes of the law means that they are often effectively silenced ${ }^{10}$ when attempting to protect themselves. If they are lucky enough to be provided with counsel, the juvenile justice system allows attorneys who represent minors to ignore the wishes of their minor clients and substitute the attorney's own (usually straight, always adult) judgment concerning a minor client's "best interest."

Part I includes law review articles which provide an overview of the issues facing queer youth. Part II is a collection of recent reports, studies, and briefings that provide statistical data, investigative reporting, and personal narratives that may be useful to those working in this area. The bibliography then focuses on specific topics. Part III collects articles addressing adolescent sexuality. Part IV addresses trans and gender nonconforming youth, and Part V deals with the related topic of institutionalization of queer youth. Part VI collects materials discussing the treatment of queer kids in the juvenile justice system, including out-of-home care. Part VII, the largest part of the Bibliography, discusses the multiple ways the education system impacts queer

9. See SAVIN-WILliAMS, supra note 6 , at $117-22$ (discussing studies indicating that the average age of first same-sex attraction is around the age of ten for males and twelve for females); HUMAN RIGHTS WATCH, HATRED IN THE HALLWAYS 17-19 (2001), http://www.hrw.org/reports/2001/uslgbt/ (indicating that girls are often aware of their attractions to other girls at age ten and have their first same-sex experience at fifteen; that boys are aware at age nine and have their first same-sex experience around the age of thirteen; and that these teens begin to self-identify as lesbian or gay at sixteen).

10. Minors can be forcibly institutionalized by their parents or guardians without due process, do not have the right to counsel in family court to advocate for their positions or wishes, and have extremely limited abilities to enter contracts, consent to health care, or receive sex education on their own behalf.

11. The statutes and rules governing the representation of minors allow, and even encourage, attomeys to substitute their own beliefs as to what is in the "best interest" of their clients instead of providing the type of advocacy adult clients receive. See Emily Buss, "You're My What?" The Problems of Children's Misperceptions of Their Lawyers' Roles, 64 FORDHAM L. REV. 1699 (1996); Robert E. Shepard \& Sharon S. England, "I Know the Child is My Client, But Who Am I?," 64 FordHAM L. Rev. 1917,1942 (1996). Both of these pieces were in the Fordham Symposium, Ethical Issues in the Legal Representation of Children, 64 FORDHAM L. REV. 1279 (1996) [hereinafter "1996 Symposium"]. In 2006, another conference aptly subtitled "Ten Years After Fordham" revisited the question of representing children; the resulting articles were collected in Symposium, Special Issues on Legal Representation of Children, 6 NEV. L.J. 571 (2006) [hereinafter "2006 Symposium"]. 
kids. This part is divided into sections addressing school violence issues, constitutional claims, the formation of gay student groups, and separate queer schools, as well as a section on Canadian articles dealing with queer youth in educational settings. Queer youths' access to health care is discussed in Part VIII, and Part IX covers immigration and asylum articles.

While the topical subject headings provide structure and easy entry into specific problems facing queer youth, it is important for a researcher to realize that there will often be substantial overlap of these areas. For example, access to health care may well involve access to health information in a school setting. Likewise, the issues involved in suing for failure to protect a queer youth from harm would be substantially the same whether the responsible organization was a school or a group home. Representing youth almost always involves dealing with the multiple authorities that routinely affect their lives such as schools, the juvenile justice system, and parents.

Finally, where I have been unable to find articles directly addressing queer youth on a specific legal topic, I have included articles that focus on the legal representation of queer adults or youth in general. One such area is a minor's right to access health care; another is the burgeoning area of Gender Identity Disorder (GID). If, for example, one were considering bringing suit against a parent or a facility for forced conversion therapy, there are several articles that deal with the conversion or reparative therapy of queer adults that would be extremely useful in such an endeavor.

\section{OVERVIEW}

The articles collected here provide an overview of the issues faced by queer youth; the sources cited within the articles themselves provide an introduction into the social science materials on this topic. Many of the legal reforms suggested or documented in these works are based on studies done in the past thirty years documenting the plight of queer or "at risk" youth. If a particular subsection of one of the articles below addresses one of the topical areas specifically addressed in this Bibliography, the article is referenced again within that topic and the relevant portions of the text are noted in the annotation.

Client-Centered Advocacy on Behalf of At-Risk LGBT Youth, 26 N.Y.U. REV. L. \& SOC. CHANGE 221 (2001) (transcript of symposium proceedings). This is a transcript of a panel in which the participants detailed personal experiences working with queer youth and the issues confronting them. The piece highlights the overlapping legal problems queer kids confront and how their age makes normal legal solutions that are applicable to queer adults in a similar situation ineffective or unusable. 
Elvia R. Arriola, The Penalties for Puppy Love: Institutionalized Violence Against Lesbian, Gay, Bisexual and Transgendered Youth, 1 J. GENDER RACE \& JUST. 429 (1998). This article is an in-depth look at psychosocial frameworks in our culture that marginalize and punish queer kids. The author provides extensive quotes from the San Francisco Human Rights Commission hearing on queer youth ${ }^{12}$ that illustrate the violence faced by sexually nonconforming youth in their daily existence.

Barbara Fedders, Coming Out for Kids: Recognizing, Respecting, and Representing LGBTQ Youth, 6 NEV. L.J. 774 (2006). This piece, written for the second major conference on representing children, ${ }^{13}$ contains a summary of the many court cases and issues affecting queer kids in the United States. The final portion of the article details separate and distinct advocacy strategies that should be used when representing queer kids, from addressing transgender youth by their chosen names to maintaining a network of local queer-sensitive providers to whom queer clients can be referred.

Bruce MacDougall, The Legally Queer Child, 49 MCGILL L.J. 1057 (2004). This is the only Canadian law review article that addresses queer youth in general, rather than in relation to a particular case. It provides an overview of how the presumption of child heterosexuality permeates Canadian jurisprudence to the detriment of queer youth. It also provides cites to several Canadian cases involving or affecting queer youth.

Karen Moulding \& Lesbian, Gay, Bisexual \& Transgender Comm., NAT'L LAWYER's GuILD, SEXUAL ORIENTATION AND THE LAW (West 2007), available at $2007 \mathrm{WL}$ Sexorient 12:1. Chapter 12 of this two-volume practitioner's loose-leaf publication addresses the myriad ways juvenile sexual orientation can have a legal impact, from juvenile court to public schools, and from the mental health system to emancipation and AIDS treatment. Unfortunately, while the treatise indicated that it is updated through 2007, many of the footnotes to cases, law review articles, and social science studies in this particular chapter are from the mid-1990s and before.

Angelo Pantazis, Lesbian and Gay Youth in Law, 117 S. AFR. L.J. 51 (2000). This article provides an overview of gay and lesbian experiences in

12. Lesbian, Gay, Bisexual, Transgender, Queer and Questioning Youth: Public Hearing Before the San Francisco Youth Comm'n and the City and County of San Francisco Human Rights Comm'n 68 (1996).

13. See 2006 Symposium, supra note 11. In the ten years between the Fordham Conference in 1996 and the Nevada Conference in 2006, the importance of respecting and protecting a client's sexuality or gender identity became recognized as a necessity for child advocates. 
adolescence supported by extensive footnoting to social science materials worldwide. Then, focusing specifically on South Africa, the author suggests specific changes in legislation and social programming that could both lessen the negative impact government has on queer youth and provide more positive support to this at-risk population.

Ruthann Robson, Our Children: Kids of Queer Parents \& Kids Who Are Queer: Looking at Sexual Minority Rights from a Different Perspective, 64 ALB. L. REV. 915 (2001). Robson was one of the first legal academics to clearly link the treatment of queer youth to society's treatment of gay and lesbian parents. Part III of this article provides a good overview of legal issues affecting sexual minority youth, which range from involuntary psychiatric treatment to juvenile justice issues and education litigation on behalf of queer teens.

Teemu Ruskola, Minor Disregard: The Legal Construction of the Fantasy that Gay and Lesbian Youth Do Not Exist, 8 YALE J.L. \& FEMINISM 269 (1996). Ruskola discusses the complex harm done to queer youth by a culture that virtually erases them through the assumption that all minors are or should be heterosexual. The article explores how this erasure of queer sexuality limits the ability of society to respect and assist queer kids.

\section{REPORTS, STUDIES, AND BRIEFINGS}

The major reports, studies, and briefings listed below are all published since 2000 and should assist scholars, litigators, reformers, and policymakers working in this area by providing statistical documentation and first-person narratives of the problems faced by queer youth. Though individual psychosocial or scientific studies have not been included, many such studies are listed in the references, addenda, and appendices of the reports listed below. While many of the reports focus on a particular issue area or topic, they are listed together because queer youth rarely face only one particular type of problem. ${ }^{14}$ Grouping the reports should allow researchers to understand both the scope of the problems faced by queer kids and the breadth of the material available. Where a report is issued periodically, only the most recent is listed.

14. It is not unlikely for a child targeted by family or by peers at school to cycle through the juvenile justice system, out-of-home placements, and the streets, while intermittently dropping in and

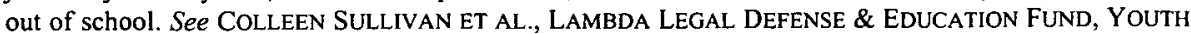
IN THE MARGINS: A REPORT ON THE UNMET NEEDS OF LESBIAN, GAY, BISEXUAL AND TRANSGENDER ADOLESCENTS IN FOSTER CARE 9 (reprint ed. 2005), available at http://www.jimcaseyyouth.org/docs/ youthinthemargins_2001.pdf. 


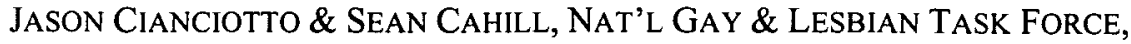
Youth IN THE CROSSHAIRS: THE THIRD WAVE OF EX-GAY ACTIVISM (2006), available at http://thetaskforce.org/downloads/reports/reports/YouthInThe Crosshairs.pdf. This report explores the growing phenomena of ex-gay "reparative" or "conversion" therapy programs targeted at queer youth. The seventy-eight page report provides examples of how the programs are sold to parents, how they are supported by religious organizations, and the types of treatment and mistreatment youth have faced in the programs. ${ }^{15}$ The report also details academic research into the use and misuse of scientific studies by therapists to justify conversion therapy treatment for children.

Nicholas Ray, Nat'l Gay \& Lesbian Task force Policy Inst. \& NAT'L COALITION FOR THE HOMELESS, LESBIAN, GAY, BISEXUAL AND TRANSGENDER YOUTH: AN EPIDEMIC OF HOMELESSNESS (2006), available at http://www.thetaskforce.org/reports_and_research/Homeless_Youth (registration required). This 185-page report provides a comprehensive look at queer homeless youth, including causation, physical and mental health concerns, and experiences of queer youth in the shelter system. In addition, the report profiles five social service agencies around the United States that have implemented programs targeting services to queer youth. The report ends with policy recommendations and twenty pages of medical, psychosocial, and governmental articles and references. It also includes an addendum listing peerreviewed studies on queer homeless youth. This is an excellent source for anyone working on this issue or litigating on behalf of queer homeless youth.

Shannan Wilber et AL., Child Welfare League of AM., CWLA Best Practices Guidelines: Serving LGBT Youth IN OUt-OF-Home CARE (2006), available at http://www.lscsf.org/publications/bestpracticeslgbtyouth.pdf. This work grew out of the recognition of the significant harm befalling queer youth placed in out-of-home care across the country. According to the authors, their goal was to provide model standards or "best practices" for child welfare and juvenile justice agency personnel to use in serving queer youth and in working to reform the juvenile justice system to reduce the harm the system inflicts on those it seeks to serve. ${ }^{16}$ The work also provides a useful list of references.

15. The system's techniques include aversive conditioning techniques involving electroshock. JASON CIANCIOTTO \& SEAN CAHILl, NAT'L GAY \& LESBIAN TASK FORCE, YOUTH IN THE CROSSHAIRS: THE THIRD WAVE OF EX-GAY ACTIVISM 71 (2006), available at http://thetaskforce.org/downloads/ reports/reports/YouthInTheCrosshairs.pdf.

16. Shannan Wilber et al., Child Welfare league of Am., CWLA Best Practices GUIDELINES: SERVING LGBT YOUTH IN OUT-OF-HOME CARE at $x$-xi (2006). 
RoB WoronofF et AL., ChILd Welfare League of AM. \& LAMBDA LEGal Def. AND Educ. Fund, OUT OF THE MARgINS: A REPORT ON THE REGIONAL LISTENING FORUMS HIGHLIGHTING THE EXPERIENCES OF LESBIAN, GAy, BISEXUAL, TRANSGENDER, AND Questioning YOUTH IN CARE (2006), available at http://www.cwla.org/ programs/culture/outofthemargins.pdf. CWLA and Lambda Legal organized fora across the country to listen to queer youth, caregivers, child welfare workers, legal professionals, and others discussing the experiences of LGBT youth in foster care. This 157-page report contains the quotes, anecdotes, suggestions, and experiences of the participants, as well as summaries of the questionnaire and forum findings. This is an excellent resource for those seeking to reform the juvenile care system on behalf of queer youth.

HUMAN RIGHTS WATCH \& ACLU, CUSTODY AND CONTROL: CONDITIONS OF CONFINEMENT IN NEW YORK's JUVENILE PRISONS FOR GIRLS (2006), available at http://hrw.org/reports/2006/ us0906/us0906web.pdf. While not focused on the treatment of lesbians and gender nonconformists, this report does specifically document discrimination and harassment of queer girls in New York's juvenile prisons. The report also documents the mentally and physically abusive treatment inflicted on all of the inmates, and indicates that the system has a "propensity to single out certain girls for harsh treatment" based on their perceived sexual or gender identity. ${ }^{17}$

Gay, Lesbian \& Straight EduCATION NETWORK, THE 2005 NATIONAL SCHOOL CLIMATE SURVEY, available at http://www.glsen.org/binarydata/GLSEN_ATTACHMENTS/file/585-1.pdf. GLSEN has published this survey, which documents the educational experiences of students who selfidentify as queer, every other year since 1999. Each survey provides a wealth of statistical information and is often cited in articles addressing the need for education reforms to curtail in-school violence, harassment, and bullying directed at queer kids.

Gay, Lesbian \& Straight EdUCATION Network, From TEasing to TORMENT: SCHOOL CLIMATE IN AMERICA (2005), available at http://www.glsen.org/binary-data/GLSEN_ATTACHMENTS/file/499-1.pdf. This report, unlike the biennial school climate surveys, is based on a survey of 3450 students and 1011 secondary school teachers without regard to the sexual orientation of the participants. The survey, conducted by Harris Interactive, Inc., collected data on all types of bullying and harassment regardless of the

17. HuMAN RIGHTS WATCH \& ACLU, CUSTODY AND CONTROL: CONDITIONS OF CONFINEMENT IN NEW YORK'S JUVENILE PRISONS FOR GIRLS 75-76 (2006), available at http://hrw.org/reports/2006/us0906/us0906web.pdf. 
perceived sexual orientation or gender identity of the victim. The result is a comprehensive collection of statistics useful for those working or writing in the area of school safety.

Cal. Safe Schools Coalition \& 4-H Center for Youth Dev., U.C. Davis, SAFE Place to Learn: CONSEQUeNCES OF HaRASSMENT Based ON

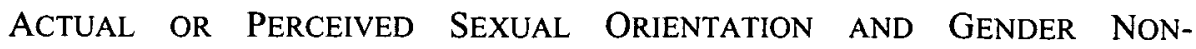
CONFORMITY AND STEPS FOR MAKING SCHOOLS SAFER (2004), available at http://www.casafeschools.org/SafePlacetoLearnLow.pdf. This report was undertaken after California passed a law directly aimed at making school a safer place for queer students. ${ }^{18}$ It distills data from two major surveys of California students, and concludes that, four years after the enactment of this law, harassment and violence targeting these students is a "persistent and prevalent problem." 19 Besides providing an extensive breakdown of the data, the report offers specific recommendations for schools and state policymakers.

Am. AsS'N of Univ. Women, Hostile Hallways: Bullying, Teasing, AND SEXUAL HARASSMENT IN SCHOOL (2001), available at http://www.aauw.org/research/upload/hostilehallways.pdf. This is a follow-up study to AAUW's 1993 report, which first documented the extent of sexual harassment in public schools. Although not specifically aimed at examining queer youth, the study does collect information on students harassed on the basis of perceived sexual orientation. The report provides personal narratives, a chapter assessing the impact of harassment on students, a discussion of the type of students who harass, and a summary of major findings.

HUMAN RightS WATCH, HATRED IN THE HALLWAYS (2001), available at http://www.hrw.org/reports/2001/uslgbt/toc.htm. HRW interviewed hundreds of students and education professionals in seven states during the 1999-2000 school year. This report, almost 300 pages long, is filled with personal narratives from students and adults, as well as other source material from social and scientific studies, policy papers, statutes, and case citations. The amount of research information collected is impressive and should not be overlooked merely because of its age.

18. California Student Safety and Violence Prevention Act of 2000, 1999 Cal. Stat. ch. 587 (prohibiting discrimination or harassment in public schools on the basis of actual or perceived sexual orientation or gender).

19. Cal. Safe Schools Coalition \& 4-H Center for Youth DeV., U.C. Davis, Safe Place to

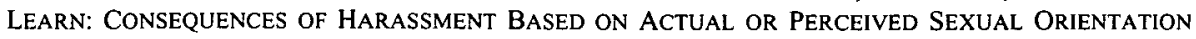
AND GENDER NON-CONFORMITY AND STEPS FOR MAKING SCHOOLS SAFER 2 (2004), available at http://www.casafeschools.org/SafePlacetoLeamLow.pdf. 
Colleen Sullivan et al., Lambda Legal Defense \& Education Fund, YOUTH IN THE MARGINS: A REPORT ON THE UNMET NEEDS OF LESBIAN, Gay, Bisexual, and Transgender Adolescents in Foster Care (2d ed. 2005), available at http://www.jimcaseyyouth.org/docs/ youthinthemargins_2001.pdf. This report, originally released in 2001, presents the findings of a survey of child welfare agency policies and practices regarding queer youth in fourteen states. Also included are relevant statutes, administrative code sections, and manuals covering policy areas such as foster parent and staff training, non-discrimination policies, and services and programs specifically targeting queer youth.

RANDI FEINSTIEN ET AL., JUSTICE FOR ALL? A REPORT ON LESBIAN, GAY, BISEXUAL AND TRANSGENDERED YOUTH IN THE NEW YORK JUVENILE JUSTICE SYSTEM (2001), available at http://www.urbanjustice.org/pdf/publications/ lesbianandgay/justiceforallreport.pdf. The report is a combination of social science research and personal interviews with New York juvenile justice professionals and queer youth. Claiming to be the first study of its kind, the report presents a horrifying picture of the mistreatment faced by queer youth enmeshed in the New York juvenile justice system. As with many of the other reports, it ends with recommendations and a useful bibliography.

\section{Adolescent SeXuality}

Adolescent sexuality is a frightening prospect for most adults, ${ }^{20}$ and society seems to swing between the extremes of either pretending it does not exist or trying to control or even criminalize its existence. ${ }^{21}$ As with other aspects of their lives, queer kids' sexuality is likely to be ignored or excluded ${ }^{22}$ but at the same time is liable to be more severely punished than adolescent heterosexuality. ${ }^{23}$ The articles below address youth sexuality in general; most address queer youth sexuality at least in part. The topics confronted are sex education, including abstinence-only programs and the provision of HIV/AIDS information to teens; youth prostitution; and the criminalization of consensual queer sex between minors. Several of the articles discuss the Kansas Supreme

20. See, e.g., Dana M. Northcraft, A Nation Scared: Children, Sex, and the Denial of Humanity: A Review Essay on Judith Levine's Harmful to Minors: The Perils of Protecting Children from Sex, 12 AM. U. J. GENDER SOC. POL'Y \& L. 483, 486 (2004) (citing Levine's focus on societal fear of adolescent sexuality and society's reaction to that fear with attempts to eradicate sex from the lives of minors).

21. See, e.g., Libby Adler, An Essay on the Production of Youth Prostitution, 55 ME. L. REV. 191, 196 (2002) (commenting on several laws proscribing certain sexual behaviors).

22. See James McGrath, Abstinence-Only Adolescent Education: Ineffective, Unpopular, and Unconstitutional, 38 U.S.F. L. REV. 665, 681 (2004) (discussing the exclusion of gay and lesbian students from sex-education programs).

23. See, e.g., State v. Limon, 122 P.3d 22 (Kan. 2005). 
Court case State v. Limon, ${ }^{24}$ which, citing Lawrence v. Texas ${ }^{25}$ and Romer v. Evans, ${ }^{26}$ found unconstitutional a Kansas statute effectively penalizing consensual sex between same-sex youth more severely than that between heterosexual teens.

Libby Adler, An Essay on the Production of Youth Prostitution, $55 \mathrm{ME}$. L. REV. 191 (2002). Although this essay focuses on youth prostitution in general, the author is highly cognizant that queer youth are far more likely to be involved in prostitution than their straight counterparts. The essay argues that the image of the "exploited innocent" blinds policy and lawmakers to the complexity of youth agency and youth prostitution. It further maintains that such disregard leads to a consistent failure to make meaningful inroads in helping at-risk youth.

Nancy Bourke, Comment, Heeding the Equal Protection Clause in the Case of State v. Limon and in Other Instances of Discriminatory Romeo and Juliet Statutes, 12 WIDENER L. REV. 613 (2006). This student work was written prior to the Kansas Supreme Court finding that the state's unlawful voluntary sexual relations statute was unconstitutional, although it provides an epilogue that discusses the decision. The piece follows Limon through the judicial system and applies a detailed equal protection analysis that argues the statute is unconstitutional under Lawrence and Romer.

Joseph Evall, Sexual Orientation and Adoptive Matching, 25 FAM. L.Q. 347 (1991). The article supports the right of lesbian and gay parents to adopt and suggests that these families might be those best-suited for adopting HIVpositive or queer youth. However, the author does not support "matching," in the sense that child welfare agencies often match adoptees and families along racial or religious lines. Rather, he urges agencies to seek out parents of all sexual orientations who would be supportive of a queer child's sexuality.

Alyssa B. Heumann, Sexuality and HIV/AIDS Education Curricula, 4 GEO. J. GENDER \& L. 439 (2002). This is a very useful collection of state laws concerning sexuality in education programs. Note that while the piece is wellfootnoted, there is minimal discussion of individual statutes. Topics covered include HIV/AIDS education, sexual orientation, and abstinence programs. A

24. Id. (holding unconstitutional on equal protection grounds a state statute providing for substantially lesser sanctions for consensual sexual relations between an adult and a minor if the couple are heterosexual).

25. Lawrence v. Texas, 539 U.S. 558 (2003) (holding Texas sodomy statute unconstitutional).

26. Romer v. Evans, 517 U.S. 620 (1996) (holding unconstitutional a state constitutional amendment that precluded anti-discrimination legislation or executive policies from including protection for homosexuals). 
portion of the material was updated in the Journal's 2005 annual review of gender and sexuality law. ${ }^{27}$

James McGrath, Abstinence-Only Adolescent Education: Ineffective, Unpopular, and Unconstitutional, 38 U.S.F. L. REV. 665 (2004). Arguing that abstinence-only programs are ineffective and dangerous, McGrath highlights the danger of such programs based on their failure to deal with HIV and STD transmission. Part III of the article focuses on the inapplicability of such programs to the lives of queer students and further argues that this creates equal protection issues, insofar as queer students are denied effective information about protecting themselves from disease.

Dana M. Northcraft, A Nation Scared: Children, Sex, and the Denial of Humanity: A Review Essay on Judith Levine's Harmful to Minors: The Perils of Protecting Children from Sex, 12 AM. U. J. GENDER SoC. POL'Y \& L. 483 (2004). Although structured as a book review, this piece also provides information on the history and laws regulating the sexuality of minors, including queer youth. These include obscenity laws, restrictions on abortion, statutory rape laws, and the regulation of sex education curricula. The author then explores each type of law and argues that they reinforce harmful gender stereotypes.

Sabrina A. Perelman, A Step in the Right Direction: How Kansas v. Limon Indicates a Brighter Future for Gay Rights Under Lawrence v. Texas, 7 GEO. J. GENDER \& L. 217 (2006). This student note argues that the Kansas Supreme Court's decision in Limon is the first decision that affirmatively applies a broad reading of Lawrence to declare a discriminatory statute unconstitutional. Perelman suggests that by finding the substantive due process and equalprotection analysis "inevitably linked," the Court is reading Lawrence and Romer to require more than a "toothless" rational basis review when discrimination is directed specifically toward gays and lesbians.

Naomi K. Seiler, Abstinence-Only Education and Privacy, 24 WOMEN'S RTS. L. REP. 27 (2002). The article looks at the potential harm of abstinenceonly programs on student privacy rights and explains that many abstinence programs either implicitly or explicitly steer their audiences away from samesex activities, often by explicit condemnation of homosexual activity. ${ }^{28}$

27. See Alyssa Varley, Sexuality in Education, 6 GEO. J. GENDER \& L. 533 (2005).

28. Naomi K. Seiler, Abstinence-Only Education and Privacy, 24 WOMEN'S RTS. L. REP. 27,36 (2002). 
Kate Sutherland, From Jailbird to Jailbait: Age of Consent Laws and the Construction of Teenage Sexualities, 9 WM. \& MARY J. WOMEN \& L. 313 (2003). This piece discusses legal and non-legal regulation of adolescent sexuality and the way that regulation actually shapes teenage sexuality. While the article focuses primarily on heterosexuality, it includes a section on the punishment of same-sex activities of minors. The piece was published prior to the Kansas Supreme Court's reversal of Matthew Limon's sentence for samesex consensual sexual activity. ${ }^{29}$

Shulamit H. Shvartsman, "Romeo and Romeo": An Examination of Limon v. Kansas in Light of Lawrence v. Texas, 35 SETON HALL L. REV. 359 (2004). Published prior to the Kansas Supreme Court's decision invalidating the law under which Limon was sentenced, this piece discusses the potential impact of Lawrence in the case.

Recent Cases, Kansas Supreme Court Invalidates Unequal Punishments for Homosexual and Heterosexual Teenage Sex Offenders, 119 HARV. L. REV. 2276 (2006). This very short case comment suggests that the Kansas Supreme Court's decision invalidating the state statute misapplied the holding in Lawrence.

\section{TRansgendered Youth AND the USE of Gender Identity Disorder (GID) TO TARGET GENDER-NONCONFORMING YOUTH}

Homosexuality as a specific mental disorder was removed from the American Psychiatric Association's Diagnostic and Statistical Manual of Mental Disorders ${ }^{30}$ in 1973 and did not appear in the 1980 edition. ${ }^{31}$ However, a new disorder called Gender Identity Disorder (GID), one specifically aimed at queer youth, was created for inclusion in that edition. ${ }^{32}$ Many of those seeking to "cure" or "prevent" homosexuality in children now focus on an amorphous set of gender identity disorders. A diagnosis of GID often provides support for the involuntary commitment of queer youth for treatment. These treatments are

29. See supra notes 23-26 and accompanying text.

30. AMERICAN PSYCHIATRIC ASSOCIATION, DIAGNOSTIC AND STATISTICAL MANUAL OF MENTAL DISORDERS, DSM-II, 44 (2d ed. 1968) (7th prtg. 1974).

31. American PSyChiatric association, Diagnostic and Statistical Manual of MEnTal DISORDERS, DSM-III (3d ed. 1980).

32. Id. See PHYLLIS BURKE, GENDER SHOCK 60-66 (1996). Burke's book, now out of print, was the first to examine the misuse and mistreatment of gender nonconforming children. Using narratives taken directly from the pages of scientific studies, the work is essential reading for anyone interested in GID. While not well-footnoted, the bibliography of scientific studies is formidable. The work is written for a lay audience, has a distinct point of view that advocates without falling into diatribe, and introduces an often-undiscussed but common and dangerous form of psychological treatment of children. 
almost always abusive, often physically harmful, ${ }^{33}$ and, unfortunately, perfectly legal.

While a GID diagnosis can be useful in providing medical support for a minor who wishes to transition to a different gender, ${ }^{34}$ it can also be used as a weapon against minors who do not wish to change genders but do not conform to societal perceptions of how a biological boy or a biological girl should look and act. Beyond "reparative therapy" treatments aimed specifically at enforcing heterosexuality, GID is treated in clinics across the country to instill gendernormative behavior ${ }^{35}$ through the use of aggressive behavior-modification techniques and drug therapies. ${ }^{36}$ Gender nonconformity is sometimes perceived as so threatening that parents have had their children removed by the state for failing to seek or support GID treatment. ${ }^{37}$

Still, there has been progress. Australia recently upheld a fourteen-yearold's self-chosen gender identity, ${ }^{38}$ and in Massachusetts and New York courts have allowed minors to insist on dressing in gender nonconforming apparel over the objections of school and group home administrators. ${ }^{39}$ Other school systems seem to accept transitioning teens diagnosed with GID without the need for legal intervention. ${ }^{40}$ Recent media stories have presented the issue in a less sensational, more matter-of-fact manner than in the past. ${ }^{41}$

Harley Abrevaya, Case Comment, Doe v. Bell, 50 N.Y.L. SCH. L. REV. 993 (2006). This case comment discusses Doe v. Bell, in which the Supreme Court of New York (a trial court) found that a teen's GID was a disability under New York's Human Rights Law, ${ }^{42}$ and that exempting her from a group home dress code was a "reasonable accommodation" required by the statute. Abrevaya

33. See supra note 5; see also infra Part $\mathrm{V}$ on liability for involuntary commitment or conversion therapy.

34. A GID diagnosis is often cited by courts in decisions that support a minor's otherwise nonconforming behavior. See Doe v. Bell, 754 N.Y.S.2d 846, 848 (N.Y. Sup. Ct. 2003); In re Alex (2004) 180 Fam. L. R. 89 (Austl.), available at http://www.austlii.edu.au/au/cases/cth/family_ct/ 2004/297.html.

35. Gender-normative behaviors are those that society recognizes as appropriate for children based entirely on the sex of an individual child. Such behavior reinforces socially prescribed ideas of gender identity and gender roles. See BURKE, supra note 32, at xix-xx.

36. Id. at $94-97$.

37. See infra note 45 and accompanying text.

38. In re Alex, 180 Fam. L. R. 89. See infra note 43 and accompanying text.

39. Doe v. Bell, 754 N.Y.S.2d 846; see Doe v. Yunits, No. 001060A, 2000 WL 33162199 (Mass. Super. Ct. Oct. 11, 2000), affd sub nom., Doe v. Brockton Sch. Comm., No. 2000-J-638, 2000 WL 33342399 (Mass. App. Ct. Nov. 30, 2000).

40. Bob Meadows et al., From Girl to Boy, PeOPLe, Oct. 30, 2006, at 92 (describing a fairly uneventful transition from female to male by a thirteen year-old middle-schooler in Wyncote, Pennsylvania); Patricia Leigh Brown, Supporting Boys or Girls When the Line Isn't Clear, N.Y. TIMES, Dec. 2, 2006, at Al (describing schools "engaged in steep learning curves to dismantle gender stereotypes" to make it easier for gender nonconforming children).

41. See Julia Reischel, Queer in the Crib, VILLAGE VOICE, June 20, 2007 (documenting reports by 20/20, Newsweek, the New York Times, and other sources on children with GID).

42. N.Y. EXEC. LAW $\S \S 292,296$ (McKinney 2004). 
argues that New York courts should narrow their definition of disability and that the Bell court should have analyzed GID issues under the standard of the Americans with Disabilities Act.

Elvia R. Arriola, The Penalties for Puppy Love: Institutionalized Violence Against Lesbian, Gay, Bisexual and Transgendered Youth, 1 J. GENDER RACE \& JUST. 429 (1998). Part III of the article explains the role the mental health system plays in the systemic abuse of adolescents who are in the process of coming out. Many mental health professionals now tell concerned parents that they can have their child treated with drugs and behavior modification therapy for putative GID, in an effort to prevent their son or daughter from becoming queer.

Hazel Beh \& Milton Diamond, Ethical Concerns Related to Treating Gender Nonconformity in Childhood and Adolescence: Lessons from the Family Court of Australia, 15 HEALTH MATRIX 239 (2005). This article discusses GID in the context of the Australia Family Court case In re Alex. ${ }^{43}$ The piece describes this particular case, gives an extensive explanation of GID diagnosis and treatment in general, and contrasts In re Alex with American decisions discussing adolescent GID cases.

Noa Ben-Asher, Paradoxes of Health and Equality: When a Boy Becomes a Girl, 16 YALE J.L. \& FEMINISM 275 (2004). This highly theoretical piece discusses an Ohio case in which a biologically-male child was removed from her $^{44}$ parents in part because they attempted to enroll her in school as a girl based on her own desires. The case was not reported, and most descriptions of the case in this article and in the Crozier piece below are from newspaper and magazine articles.

Patience W. Crozier, Forcing Boys to Be Boys: The Persecution of Gender Non-Conforming Youth, 21 B.C. THIRD WORLD L.J. 123 (2001) (reviewing Christina Hoff SOMmers, The War Against Boys: How Misguided FEMINISM IS HARMING OUR YOUNG MEN (2000)). The review explores legal enforcement of gender conformity in children, and how that enforcement actively harms queer youth. It contrasts two cases' different state responses to gender-nonconforming minors. In the Ohio case discussed above, ${ }^{45}$ the state

43. In re Alex, 180 Fam. L. R. 89 (granting permission for a thirteen year-old female diagnosed with GID to undergo treatment that would support the child's desire to be treated as a male and possibly to undergo sex reassignment surgery after the age of sixteen).

44. Female pronouns are used here, consistent with the child's identification of her gender.

45. This case was never judicially reported. For more information, see Noa Ben-Asher, Paradoxes of Health and Equality: When a Boy Becomes a Girl, 16 YALE J.L. \& FEMINISM 275 (2004). See also 
removed a child from her parents, who were allowing her to attend school as a girl though she was biologically male. In contrast, a Massachusetts court issued a preliminary injunction that forbade a school district from requiring a student to conform to gender-appropriate dress. ${ }^{46}$

Kari E. Hong, Categorical Exclusions: Exploring Legal Responses to Health Care Discrimination Against Transsexuals, 11 COLUM. J. GENDER \& L. 88 (2002). Hong argues that once the American Psychological Association stopped classifying homosexuality as a mental disorder and listed GID as a cognizable psychological condition, doctors began to use GID as a diagnosis to treat very young children for "pre-homosexuality." The article also explores some of the individual treatment methods (hormones, behavior modification, bible study, isolation, psychotropic drugs, physical restraint) that have been used to cure or prevent homosexuality, lesbianism, and transsexuality in minors and adults.

Eithne Mills, Re Alex: Adolescent Gender Identity Disorder and the Family Court of Australia, 9 DEAKIN L. REV. 365 (2004). This very short case note from an Australian law review provides details on the Australian GID case, ${ }^{47}$ including extensive background information gleaned from local newspaper and magazine sources.

Shannon Minter, Diagnosis and Treatment of Gender Identity Disorder in Children, in SISSIES \& TOMBOYS: GENDER NONCONFORMITY \& HOMOSEXUAL CHILDHOOD 9 (Matthew Rottnek ed., 1999). This piece, by an attorney with the National Center for Lesbian Rights, discusses the medical aspects of GID for a non-legal and non-medical audience. Minter, while working at NCLR, was one of the first to bring the use of GID against queer youth to public attention.

John A. Russ IV, The Gap Between Asylum Ideals and Domestic Reality: Evaluating Human Rights Conditions for Gay Americans by the United States' Own Progressive Asylum Standards, 4 U.C. DAVIS J. INT'L L. \& POL'Y 29 (1998). The author examines the abuses gay and lesbian immigrants face in their home countries, and then documents the recent liberalization of U.S. asylum laws as applied to gay and lesbian immigrants. Turning to conditions faced by gays and lesbians in the United States, he acknowledges that the United States is safer than many countries for sexual minorities. However, he argues that some of the conditions that queer individuals in the United States

John Cloud, His Name is Aurora: When a Boy Is Raised as a Girl, an Ohio Suburb Is Suddenly in the Throes of Transgender Politics, TIME, Sept. 25, 2000, at 90.

46. Doe v. Yunits, No. 0010604, 2000 WL 33162199, (Mass. Super. Ct. Oct. 11, 2000).

47. In re Alex, 180 Fam. L. R. 89. 
face, such as forced psychiatric treatment of GID or "pre-homosexuality" in children, might well constitute grounds for asylum under the United States' own progressive asylum standards.

Daphne Scholinski, After-Wards, 48 HaStings L.J. 1195 (1997). This article relates the personal experiences of a lesbian placed in a psychiatric ward from age fifteen to eighteen as a result of her gender identity disorder. She describes doctors using her GID diagnosis as a basis for trying to cure her of "pre-homosexuality."

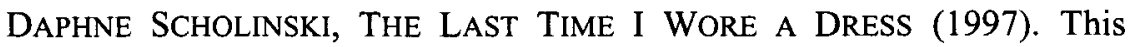
autobiography of the author of After-Wards describes the life of a young woman institutionalized in a mental hospital at fifteen for "not acting like a girl" and held there for three years on a diagnosis of GID. As a result of their documentation of their treatment, Scholinski and Lyn Duff ${ }^{48}$ are the two most well-known "survivors" of institutionalization for gender nonconformity and/or same-sex attraction.

Sonja Shield, The Doctor Won't See You Now: Rights of Transgendered Adolescents to Sex Reassignment Surgery, 31 N.Y.U. REV. L. \& SoC. CHANGE 361 (2007). This long and heavily footnoted article discusses the physical and mental impact of delayed sex reassignment surgery on adolescent transsexuals. It then explores the legal foundations of informed consent that would support a minor's ability to consent to such surgery. The piece is an excellent resource for medical, legal, and sociological sources.

Dean Spade, Resisting Medicine, Re/modeling Gender, 18 BERKELEY WOMEN'S L.J. 15 (2003). While not addressed to transgendered youth specifically, the article provides a good discussion on the medical establishment's use of GID to police gender roles. Drawing from his legal work on Doe v. Bell, ${ }^{49}$ the author discusses the implications of using GID claims to support disability discrimination allegations in "trans rights" cases. He cautions that such a litigation strategy reinforces the use of GID as a legitimate diagnosis when that same diagnosis is often used to support the institutionalization of queer youth.

48. Duff, supra note 5. Duff was initially institutionalized because her mother suspected her lesbianism but once at Rivendell, the Utah-based hospital where she was involuntarily placed, she was diagnosed with gender identity disorder. Id. at 47-48.

49. Doe v. Bell, 754 N.Y.S.2d 846 (N.Y. Sup. Ct. 2003). 


\section{INSTITUTIONALIZATION AND CONVERSION OR REPARATIVE THERAPY}

There has been a dramatic increase in the placement of minors into residential treatment programs in the past quarter-century. ${ }^{50}$ The placements most often linked to mistreatment, abuse, and even death of minors are private residential facilities that are not licensed by states or national organizations. ${ }^{51}$ Family members send queer youth ${ }^{52}$ off to be "cured," and drop them into a toxic mix of placements and unregulated programs. ${ }^{53}$ As indicated by the articles in the previous section, GID is increasingly used as a diagnosis to support institutionalization, especially when coupled with the belief that GID signals "pre-homosexuality" in children.

The horrors of reparative therapy and conversion programs are well documented, with queer youth routinely facing aversion therapy, physical behavior modification, electro-shock treatment, solitary confinement, and more. ${ }^{54}$ There is growing alarm that programs involuntarily treating queer kids are increasing because of conservative religious groups' adoption and exhortation of the tactics and claims of the "ex-gay" movement. ${ }^{55}$ The ex-gay movement asserts that homosexuality can be cured through therapy. There has been a recent trend of fundamentalist Christian leaders embracing this idea of conversion or reparative therapy, and recommending it to their followers. ${ }^{56}$

While not always focusing on queer youth, the works below describe reparative and conversion therapies generally. They offer potential legal theories that can be used on behalf of queer youth involuntarily committed on the basis of their sexuality.

50. Lois A. Weithom, Mental Hospitalization of Troublesome Youth: An Analysis of Skyrocketing Admission Rates, 40 STAN. L. REV. 773 (1988) (stating that admission rates increased four-fold between 1980 and 1984 alone); Alexander V. Tsesis, Protecting Children Against Unnecessary Institutionalization, 39 S. TEX. L. REV. 995 (1998) (noting that children with relatively mild behavior disorders are routinely institutionalized).

51. Robert Freidman et al., Unlicensed Residential Programs: The Next Challenge in Protecting Youth, 76 AM. J. ORTHOPSYCHIATRY 295 (2006).

52. See Leaf, supra note 4.

53. In a pamphlet written for principals and other school personnel, the American Psychological Association states ' $[t]$ he most important fact about 'reparative therapy,' also known as 'conversion' therapy, is that it is based on an understanding of homosexuality that has been rejected by all the major health and mental health professions." Comm. on Lesbian, Gay \& Bisexual Concerns, Just the Facts About Sexual Orientation \& Youth: A Primer for Principals, Educators and School Personnel, http://www.apa.org/pi/lgbc/publications/justthefacts.html (last visited Oct. 16, 2007).

54. See CIANCIOTTO \& CAHILl, supra page 457, MOURNIAN, supra note 5; Duff, infra page 469. While the treatments for "curing" homosexuality and for GID are often similar and the reasoning behind the treatments conflated, most medical professionals reject reparative or conversion therapy while supporting treatment for GID.

55. CIANCIOTTO \& CAHILL, supra page 457, at 25-30 (describing the religious right's embrace of reparative therapy and their aggressive marketing of it to parents). See Sandra G. Boodman, Vowing to Set the World, WASH. POST, Aug. 16, 2005, at Fl (discussing the growth of ex-gay ministries and noting websites and billboards directed at "confused teenagers and frantic parents").

56. Boodman, supra note 55 . 
John Alan Cohan, Parental Duties and the Right of Homosexual Minors to Refuse "Reparative" Therapy, 11 BUfF. WOMEN'S L.J. 67 (2003). This is a very short essay that discusses several of the legal theories (such as parens patria, ability to consent, child abuse, use of the U.N. Convention on the Rights of the Child) that could influence the choice of a parent to force a child into reparative therapy.

David B. Cruz, Controlling Desires: Sexual Orientation Conversion and the Limits of Knowledge and Law, 72 S. CAL. L. REv. 1297 (1999). This comprehensive article on conversion therapy provides a useful overview of the psychiatric and psychological literature on this controversial treatment. It also has a large section discussing the possibility of adults consenting to such therapy. The issue of children and minors is not addressed.

Lyn Duff, I Was a Teenage Test Case, 16 CAL. LAw. 47 (1996). A journalist looks back and describes the 178 days she endured in an out-of-state placement facility where she was placed by her mother to receive treatment for her lesbianism. She later escaped. With the assistance of Legal Services for Children and the National Center for Lesbian Rights, Duff successfully fought her re-commitment and was able to "divorce" her mother.

Laura A. Gans, Inverts, Perverts, and Converts: Sexual Orientation Conversion Therapy and Liability, 8 B.U. PUB. INT. L.J. 219 (1999). While not focused on youth, the article discusses the potential liability of conversion therapists for the harms they inflict. The piece is an early work in this area and is often cited by writers evaluating the impact and legality of conversion therapy for queer kids.

Miye A. Goishi, Unlocking the Closet Door: Protecting Children from Involuntary Civil Commitment Because of Their Sexual Orientation, 48 HASTINGS L.J. 1137 (1997). This article examines the protections that California provides to children facing involuntarily commitment. Goishi argues that vague admission standards, the power of the treating physician, and little state oversight all increase the likelihood that the personal moral standards of doctors, parents, and individual facility administrators can merge into a potentially insurmountable force brought to bear against queer teens. The author suggests that enhanced due process requirements and least restrictive alternative placement standards would help reduce the risk that queer youth would be committed solely because of their perceived sexuality.

Karolyn Ann Hicks, Comment, "Reparative" Therapy: Whether Parental Attempts to Change a Child's Sexual Orientation Can Legally Constitute Child 
Abuse, 49 AM. U. L. REV. 505 (1999). This comment places parental insistence on reparative therapies within the abuse and neglect context of New York family law. She bases her argument on the emotional and physical harm such therapies can cause queer youth.

Sana Loue, Redefining the Emotional and Psychological Abuse and Maltreatment of Children, 26 J. LEGAL MED. 311 (2005). This article, while not focused on queer youth, has a short section on the potential harms that result from forcible institutionalization of minors based on their sexuality. The author suggests that mental health providers must become far more proactive in recognizing and distinguishing inappropriate attempts by parents to commit a child based on sexuality from appropriate commitment based on an underlying mental illness.

Sonia Renee Martin, $A$ Child's Right To Be Gay: Addressing the Emotional Maltreatment of Queer Youth, 48 HASTINGS L.J. 167 (1996). Martin examines the tremendous effects of parental emotional abuse of queer youth. The article collects a number of studies that present the negative side affects of legal and non-legal parental abuse on queer youth. These side affects can include suicide, drug abuse, homelessness, prostitution, and the risk of HIV/AIDS.

Beth E. Molnar, Juveniles and Psychiatric Institutionalization: Toward Better Due Process and Treatment Review in the United States, 2 Health \& HUM. RTS. 98 (1997). The author argues that institutionalizing youth for their sexuality in an attempt to force them to become heterosexual violates the United Nations Convention on the Rights of the Child, adopted in 1998 and signed but not ratified by the United States. The work itself provides excerpts from several first-person narratives of minors who had been institutionalized to undergo conversion therapy.

Maribel Morey, The Civil Commitment of State-Dependent Minors: Resonating Discourses that Leave Her Heterosexuality and His Homosexuality Vulnerable to Scrutiny, 81 N.Y.U. L. REV. 2129 (2006). This student Note compares the governmental social agenda that led to Buck v. Bell ${ }^{57}$ with the present-day governmental agenda that attempts to promote heterosexuality (with an emphasis on dissuading male homosexuality) while simultaneously regulating and controlling female sexuality and teenage pregnancy. The author

57. Buck v. Bell, 274 U.S. 200 (1927) (upholding a state law allowing the involuntarily sterilization of a mentally incompetent woman). 
examines the role that the misuse of sexuality in diagnosing Conduct Disorder ${ }^{58}$ plays in involuntary commitments of sexually active teens.

Tyler Talbot, Comment, Reparative Therapy for Homosexual Teens: The Choice of the Teen Should Be the Only Choice Discussed, 27 J. Juv. L. 33 (2006). This student piece is fairly short and does not provide in-depth legal analysis. However, it was written by someone who personally went through three years of reparative "therapy," and, like the Scholinski and Duff narratives, ${ }^{59}$ provides a potent description of the trauma and mental anguish such "therapy" can cause.

\section{Foster CARE AND tHe JUVENILE Justice System}

Queer youth are overrepresented in all aspects of the juvenile justice system. The system itself is indifferent to their needs and can be more dangerous than any situation from which it attempts to save them. ${ }^{60}$ Physical assaults including rape and attempted murder, constant verbal harassment, isolation, attempted conversion therapies, rejection, and blame are often the face of juvenile justice for queer kids in the United States. ${ }^{61}$ In addition, queer kids' sexuality can lead to extension of placement or arbitrary designations of sex-offender status. ${ }^{62}$

Child welfare professionals have slowly begun to recognize and address the plight of queer youth. Model standards are being developed, social policy debated and devised, and child welfare educators have, to some extent, taken up the cause of queer youth in out of home placement. ${ }^{63}$ The articles below address many different aspects of queer youth interaction with the juvenile justice system, and should prove useful to anyone seeking to address the issue of state intervention in the lives of queer kids.

Rosemarie Buchanan, Young, Homeless and Gay: Shelters are Swelling with a Disproportionate Number of Teens Tossed Out by Society and Family, 22 HUM. RTS. 42 (1995). This is a short article providing some statistics on the number of queer youth who find themselves on the street, often in large part

58. "Conduct Disorder is one of the most frequently diagnosed conditions in outpatient and inpatient mental health facilities for children." AMERICAN PSYCHOLOGICAL ASSOCIATION, DIAGNOSTIC and Statistical Manual of MENTAl Health Disorders, DSM-IV (4th ed. 1994).

59. See supra note 48 and accompanying text.

60. See SUllivan ET AL., supra page 460 at 9-11; Estrada \& Marksamer, infra page 472 , at 418 21 .

61. See Peter Hahn, The Kids Are Not Alright, 14 B.U. PuB. INT, L.J. 117 (2004).

62. See id. at 125-26.

63. See supra note 6 (noting that Child Welfare devoted an entire issue to queer youth in foster care and the juvenile justice system); infra note 64 and accompanying text (discussing the Model Standards and Fostering Transitions programs). 
because of their sexuality or gender presentation. It describes several of the agencies and organizations that have sprung up to try to assist these teens.

Rudy Estrada \& Jody Marksamer, Lesbian, Gay, Bisexual and Transgender Young People in State Custody: Making the Child Welfare and Juvenile Justice System Safe for All Youth Through Litigation, Advocacy, and Education, 79 TEMP. L. REV. 415 (2006). Written in part to introduce two programs aimed at improving the condition of queer kids in state custody, ${ }^{64}$ this article provides an overview of litigation strategies used in cases brought on behalf of queer kids in the juvenile justice system. The piece also describes the two programs and explains why the authors think they will be able to assist in educating service providers to better respond to the needs of queer youth.

Miriam Aviva Friedland, Too Close to the Edge: Lesbian, Gay, Bisexual and Transgendered Youth in the Child Welfare System, 3 GEO. J. GENDER \& L. 777 (2002). Friedland provides a look at the role homophobia plays in how queer youth are pushed into the child welfare system and in how they are treated once in the system. The piece is interspersed with first-person narratives from queer youth that add emotional nuance to the scholarly descriptions of the challenges facing adolescents caught in the child welfare system.

James W. Gilliam, Jr., Towards Providing a Welcoming Home for All: Enacting a New Approach To Address the Longstanding Problems Lesbian, Gay, Bisexual, and Transgender Youth Face in the Foster Care System, 37 LOY. L.A. L. REV. 1037 (2004). The article examines the constitutionality of programs matching queer foster care youth with openly gay and lesbian families as a way to provide safe, queer-friendly homes to an underserved and at-risk population. The author compares such programs with those that take the race or religion of a foster child into consideration. He argues that the programs would survive a constitutional challenge and ameliorate a large and daunting problem.

Valerie Gwinn, Locked in the Closet: The Impact of Lawrence v. Texas on the Lives of Gay Youth in the Juvenile Justice System, 6 WHITTIER J. CHILD \& FAM. ADVOC. 437 (2007). Gwinn suggests that a large part of the discrimination faced by queer youth caught in the juvenile justice system is encouraged by government-sanctioned homophobia that creates and perpetuates the biases of individual administrators in the system. She then

64. The two programs are "Fostering Transitions," a joint program between CWLA and Lambda Legal, and "The Model Standards Project," a joint program between Legal Services for Children (LSC) and the National Center for Lesbian Rights (NCLR). Lambda Legal and NCLR have been co-counsel or amicus in many of the cases litigated on behalf of queer kids. 
argues that Lawrence, because it explicitly rejects the notion that people should be punished for their sexual expression, can be used to combat the discrimination queer youth face in the juvenile justice system.

Peter A. Hahn, The Kids Are Not Alright: Addressing Discriminatory Treatment of Queer Youth in Juvenile Detention and Correctional Facilities, 14 B.U. PUB. INT. L.J. 117 (2004). This student note examines the treatment of queer youth in juvenile facilities, and how queer kids are more likely than their straight counterparts to end up in the juvenile justice system. The piece also suggests several distinct legal causes of action that could be used to force reform, such as $\S 1983$, the Civil Rights of Institutionalized Persons Act, and state reviews of the administrative agencies running juvenile facilities.

Ethan M. Krasnoo, Foster Care and Adoption, 7 GEO J. GENDER \& L. 999 (2006). Although this short update is primarily focused on foster care and adoption in general, there is a short section that discusses queer kids in foster care.

Nancy D. Polikoff, Resisting "Don't Ask, Don't Tell" in the Licensing of Lesbian and Gay Foster Parents: Why Openness Will Benefit Lesbian and Gay Youth, 48 HASTINGS L.J. 1183 (1997). Polikoff suggests the state sends a powerful positive message when it openly licenses gay and lesbian foster parents and argues that a "don't ask, don't tell" policy does not go far enough. The piece predicts that a system that openly supports gay and lesbian foster parents will be more likely to openly support and provide services for the queer youth in its care.

Colleen A. Sullivan, Kids, Courts and Queers: Lesbian and Gay Youth in the Juvenile Justice and Foster Care Systems, 6 LAW \& SEXUALITY 31 (1996). Interspersing narratives from queer teens describing their lives with descriptions of the impact the juvenile justice system has on queer kids, the author paints a frightening picture of the forces that can align to actively harm queer youth. This is one of the earliest articles specifically discussing queer youth in the juvenile justice system.

Laurie Schaffner, Violence and Female Delinquency: Gender Transgressions and Gender Invisibility, 14 BERKELEY WOMEN'S L.J. 40 (1999). This article has a very short section on "homophobia as violence",65 that discusses some of the ways homophobia affects how female juvenile delinquents are seen and see themselves as both more violent and at the same

65. Laurie Schaffner, Violence and Female Delinquency: Gender Trangressions and Gender Invisibility, 14 BERKELEY WOMEN'S L.J. 40, 60-62 (1999). 
time more prone to being victimized than non-queer female juvenile delinquents.

Anne Tamar-Mattis, Implications of AB 458 for California LGBTQ Youth in Foster Care, 14 LAW \& SEXUALITY 149 (2005). This work discusses California's Foster Care Nondiscrimination Act (commonly called "AB 458 "), ${ }^{66}$ which explicitly prohibits harassment or discrimination of foster care youth on the basis of sexual orientation, gender identity, or HIV status. Written soon after the act was passed, the piece suggests that those litigating on behalf of queer foster youth should use racial discrimination cases in foster care and general queer civil rights cases as guides in litigating under AB 458.

Joseph J. Wardenski, Comment, A Minor Exception? The Impact of Lawrence v. Texas on LGBT Youth, 95 J. CRIM. L. \& CRIMINOLOGY 1363 (2005). The author addresses the "minor exception in Lawrence",67 and suggests that cases such as Lofton v. Department of Children and Family Services ${ }^{68}$ and the lower court opinions in Limon ${ }^{69}$ notwithstanding, the holding in Lawrence cannot help but ease the plight of queer youth. ${ }^{70} \mathrm{He}$ reasons that the language of equality and dignity the opinion uses in rejecting the discriminatory premise of Bowers v. Hardwick ${ }^{71}$ reduces the likelihood that social animus and discrimination can justify biased treatment of queer youth. ${ }^{72}$

\section{EDUCATION}

This is the largest part of the Bibliography, because the education arena has seen the most litigation and reform on behalf of queer kids. Given the number of articles on this topic, this Part is divided into an overview Section and topical Sections on bullying and harassment, constitutional concerns, student groups such as gay/straight alliances (GSAs), separate schools for queer students, and a selection of Canadian education articles involving queer youth.

66. 2003 Cal. Stat. 331 .

67. Joseph J. Wardenski, Comment, A Minor Exception? The Impact of Lawrence v. Texas on LGBT Youth, 95 J. CRIM. L. \& CRIMINOLOGY 1363, 1407 (2005). Justice Kennedy's majority opinion states in part:

The present case does not involve minors. It does not involve persons who might be injured or coerced or who are situated in relationships where consent might not easily be refused. It does not involve public conduct or prostitution. It does not involve whether the government must give formal recognition to any relationship that homosexual persons seek to enter.

Lawrence v. Texas, 539 U.S. 558, 578 (2003).

68. Lofton v. Sec'y of Dep't of Children \& Family Services, 358 F.3d 804 (11th Cir. 2004), (upholding a Florida law prohibiting gays and lesbians from adopting children).

69. State v. Limon, 83 P.3d 229 (Kan. Ct. App. 2004).

70. Wardenski, supra note 67 , at 1369.

71. Bowers v. Hardwick, 478 U.S. 186 (1986).

72. Wardenski, supra note 67 , at $1389-94$. 
The two largest areas of litigation involving queer students and education are peer harassment and GSAs. These areas are also those in which queer students have been the most effective. Since Jamie Nabozny was awarded damages for the physical abuse he suffered at the hands of fellow students, ${ }^{73}$ school districts have begun to take peer harassment seriously. Similarly, after the initial battle with the Salt Lake City's School District was won, queer students have generally been successful in their fight to establish GSAs. Now that GSAs exist in a large number of schools, educators see that they have positive affects on the students actively involved in the clubs and provide safer schools for all queer students. ${ }^{74}$

\section{A. General Education Articles}

Donna I. Dennis \& Ruth E. Harlow, Gay Youth and the Right to Education, 4 YALE L. \& POL'Y REV. 446 (1986). This is a very early piece on the problems facing queer students-so early that the authors rely on the anecdotal precursors to the GLSEN surveys and other studies concerning the harassment of queer kids in educational settings. ${ }^{75}$ The authors propose that class action suits be brought on behalf of queer kids based on equal protection and right to education clauses in state constitutions. The article examines the possible defenses school systems could use and offers litigation strategies to counter them.

David S. Doty, Finding a Third Way: The Use of Public Engagement and ADR To Bring School Communities Together for the Safety of Gay Students, 12 HASTINGS WOMEN'S L.J. 39 (2001). Doty describes the conflicting legal demands placed on school systems from those groups seeking to protect and support queer youth in school and those groups that challenge these actions using parental rights arguments and the First Amendment's religion clauses. Detailing the experience of the Modesto City School System's use of public

73. See sources cited infra note 78 discussing Nabozny's suit.

74. Camille Lee, The Impact of Belonging to a High School Gay/Straight Alliance, HIGH SCH. J. Feb.-Mar. 2002, at 13, 25 (indicating improved connection to school, increased academic standing, and overall feeling of empowerment resulting from establishment of GSA); see also GAY, LESBIAN AND STRAight EdUCATION NETWORK, FROM TEASING TO TORMENT, supra page 458, at vxi (reporting that, where schools have a GSA or a similar club, LGBTQ students feel safer, miss school less, and feel a greater sense of belonging); Stephanie K. Swann \& Christina A. Spivey, The Relationship Between SelfEsteem and Lesbian Identity During Adolescence, 21 CHILD \& ADOL. SOC. WORK J. 629, 642-43 (2004) (finding that "group membership may act as a protective factor for [adolescent] self-esteem" and arguing that "the development of [GSAs] in schools ... should continue to be a priority for the social work profession").

75. Donna I. Dennis \& Ruth E. Harlow, Gay Youth and the Right to Education, 4 YALE L. \& PoL'Y REV. 446, 448 n.6 (1986). Recent studies confirm the anecdotal evidence provided by Dennis and Harlow. See GLSEN, 2005 SCHOOL Climate SURVEY, supra note 1; HUMAN RIGHTS WATCH, supra note 9; Diane E. Elze, Gay, Lesbian, and Bisexual Youths' Perceptions of Their High School Environments and Comfort in School, 25 CHILDREN \& SCH. 225 (2003). 
engagement and alternative dispute resolution principles, he suggests that school systems can successfully resolve these policy conflicts through mediation rather than litigation.

Boaz I. Green, Discussion and Expression of Gender and Sexuality in Schools, 5 GEO. J. GENDER \& L. 329 (2004). This short article is a survey of the law as applied to queer students and staff in educational settings. There is an extensive listing of cases in the footnotes that would assist researchers working in this area. This is the Georgetown Journal of Gender and the Law's fifth annual review dealing with gender and sexuality in schools. ${ }^{76}$

Scott Hirschfeld, Moving Beyond the Safety Zone: A Staff Development Approach to Anti-Heterosexist Education, 29 FORDHAM URB. L.J. 611 (2001). This short piece is written by the Director of GLSEN and focuses on the hostility queer youth face from educators and school personnel. The essay documents some of the successes and failures of the safe schools programs and articulates the type of program criteria that can lead to a safe schools program fostering long-term positive change in public education.

Carlo A. Pedrioli, Lifting the Pall of Orthodoxy: The Need for Hearing a Multitude of Tongues in and Beyond the Sexual Education Curricula at Public High Schools, 13 UCLA WOMEN's L.J. 209 (2005). This short piece summarizes the harms which befall queer youth and urges public high schools to take a variety of steps, such as expanding sex education, authorizing the formation of support groups, and instituting diversity training, to help ameliorate these problems. This article is best used as an introduction to some of the problems and potential solutions in this arena.

\section{B. Addressing Violence in the School Setting: Bullying and Harassment of Queer Youth}

Kelli Kristine Armstrong, The Silent Minority Within a Minority: Focusing on the Needs of Gay Youth in our Public Schools, 24 GoldEN GATE U. L. REV. 67 (1994). Drawing on educational and social science literature as well as newspaper stories, this student-written piece from the early 1990s provides an overview of the problems (as well as some of the attempted solutions to those problems) faced by queer students in the public schools. She describes some of the early programs, such as the "Rainbow Curriculum," Project 10, the use of

76. See Saleda S. Bryant, Discussion and Expression of Gender and Sexuality in Schools, 3 GEO. J. GENDER \& L. 525 (2002); Sean P. Greene, Discussion and Expression of Gender and Sexuality in Schools, 4 GEO. J. GENDER \& L. 421 (2003); Toki Rehder, Discussion and Expression of Gender and Sexuality in Schools, 2 GEO. J. GENDER \& L. 489 (2001); Samuel Slater \& Hannah Koopman Williams, Discussion and Expression of Gender and Sexuality in Schools, 1 GEO. J. GENDER \& L. 483 (2000). 
speaker's panels, and school support groups as successful in providing role models, positive information, and safe spaces for queer youth.

Julie A. Baird, Playing It Straight: An Analysis of Current Legal Protections to Combat Homophobia and Sexual Orientation Discrimination in Intercollegiate Athletics, 17 BERKELEY WOMEN'S L.J. 31 (2002). This piece addresses the use of Title VII and Title IX in addressing homophobia in intercollegiate athletics. Its strength lies in the first three sections of the article, which chronicle and explore the pervasiveness of homophobia and the myriad harms it causes to students and coaches alike. The author, focusing on the public perception of lesbianism in athletics, has compiled an impressive survey of public reactions to even the hint of lesbianism in college athletic programs.

Jeffrey I. Bedell, Personal Liability of School Officials Under $\$ 1983$ who Ignore Peer Harassment of Gay Students, 2003 U. ILL. L. REV. 829 (2003). In this student work, the author details the type and extent of anti-gay harassment occurring in the United States K-12 education system. He describes the lack of protection students receive from school administrators and argues that interpretations of Title IX and Title VII cannot redress anti-gay harassment. The author suggests suits against school boards and school officials such as 1983 actions. $^{77}$ Citing Nabozny ${ }^{78}$ and its progeny, the article discusses the standards a plaintiff must meet for a successful suit under $\S 1983$ and how these cases have helped to ensure safer schools for queer students.

Alycia N. Broz, Nabozny v. Podlesny: A Teenager's Struggle to End AntiGay Violence in Public Schools, 92 NW. U. L. REV. 750 (1998). This student note analyzes the Seventh Circuit's landmark decision in Nabozny v. Podlesny. The case, which was settled for nearly one million dollars, was the first of its kind and provided an effective tool for queer students to force school systems to take peer harassment claims seriously.

Vanessa H. Eisemann, Protecting the Kids in the Hall: Using Title $I X$ to Stop Student-on-Student Anti-Gay Harassment, 15 BERKELEY WOMEN'S L.J. 125 (2000). This student piece argues that school administrators are engaging in prohibited sex stereotyping if they take into consideration the perceived sexual orientation of students when making decisions on whether or not to respond to complaints of student peer harassment. Eisemann reasons that

77. 42 U.S.C. $\$ 1983(2005)$.

78. Nabozny v. Podlesny, 92 F.3d 446 (7th Cir. 1996). The Seventh Circuit remanded the case to the district court. The case was settled for $\$ 900,000$ plus medical damages after a jury finding of "intentional discrimination" by school administrators but not the school district. See Gay Ashland Student Awarded Nearly \$1 Million, CAP. TIMES, Nov. 21, 1996, at 7A. 
providing queer students a private right of action under Title IX would help ensure that queer youth have equal access to education.

Katie Feiock, The State to the Rescue: Using State Statutes to Protect Children from Peer Harassment in School, 35 COLUM. J.L. \& SOC. PROBS. 317 (2002). This student article argues that well-written state statutes are often far more effective than federal law in protecting queer youth from peer harassment. The piece is a survey of current state laws and a discussion of the differing enforcement mechanisms available depending on the state. There is also a suggested model statute that draws from the most useful aspects of the laws discussed.

Anne Gregory, Rethinking Homophobia in Sports: Legal Protections for Gay and Lesbian Athletes and Coaches, 2 DEPAUL J. SPORTS L. \& CONTEMP. PROBS. 264 (2004). This piece discusses the prevalence of homophobia in sports and the impact it has on students and coaches. It is relatively short but contains overviews of several different legal theories, from Title IX to student claims for breach of contract. They are suggested as potential remedies to students and coaches harassed or fired for their sexuality.

Susan Hanley Kosse \& Robert H. Wright, How Best to Confront the Bully: Should Title LX or Anti-Bullying Statutes Be the Answer?, 12 DUKE J. GENDER L. \& POL'Y 53 (2005). While the piece suggests that both Title IX and state anti-bullying statutes are necessary, it argues that because courts have not extended Title IX protections to discrimination based on sexual orientation, anti-bullying statutes could be more effective in combating bullying of queer kids. The article also addresses issues that arise in drafting anti-bullying statutes and the need to carefully balance First Amendment rights and limits on harmful or harassing speech.

Amy Lovell, "Other Students Always Used to Say, 'Look at the Dykes'": Protecting Students from Peer Sexual Orientation Harassment, 86 CAL. L. REV. 617 (1998). Lovell explores the failure of existing federal and state laws to adequately protect queer youth from peer harassment based on sexual orientation. After documenting the effects of this harassment on its student victims, and the gaps in existing law, she proposes a comprehensive model statute that imposes an affirmative duty on schools to take reasonable steps to combat sexual orientation-based harassment of their students.

Thomas A. Mayes, Confronting Same-Sex, Student-to-Student Sexual Harassment: Recommendations for Educators and Policy Makers, 29 FORDHAM URB. L.J. 641 (2001). The article reads recent Title VII and Title IX 
Supreme Court decisions as providing a new avenue for queer students fighting peer harassment. It also provides an excellent summary of legal and non-legal scholarship on queer kids in the educational system.

Karen L. Michaelis, Title IX and Same-Gender Sexual Harassment: School District Liability for Damages, 2000 BYU EDUC. \& L.J. 47. Though not about sexual orientation harassment, this article investigates same-sex peer harassment in education and may be helpful to someone working on sexual orientation harassment. The article provides a close look at the different liability and proof requirements under Titles VI, VII, and IX, and discusses recent Supreme Court decisions in each of these areas of the law.

Jason P. Nance \& Philip T.K. Daniel, Protecting Students From Abuse: Public School District Liability for Student Sexual Abuse Under State Child Abuse Reporting Laws, 36 J.L. \& EDUC. 33 (2007). This article outlines how child abuse reporting laws can hold school district or school personnel liable for failure to report peer abuse. Such a strategy is applicable in situations where queer youth are being abused. The authors indicate that some state child abuse reporting laws carry civil penalties and can be used even when the defendants are able to escape a $\S 1983$ suit or common law negligence liability.

Barbara Osborne, "No Drinking, No Drugs, No Lesbians": Sexual Orientation Discrimination in Intercollegiate Athletics, 17 MARQ. SPORTS L. REV. 481 (2007). This article begins with a discussion of two high profile cases in which college students fought sexual orientation discrimination on the part of coaches and athletic directors. The author then discusses the limitations of applying gender stereotyping discrimination, which is recognized under Title VII and Title IX, to cases where the discrimination is clearly based on sexual orientation.

Jennifer C. Pizer \& Doreena P. Wong, Arresting "The Plague of Violence": California's Unruh Act Requires School Officials To Act Against Anti-Gay Peer Abuse, 12 STAN. L. \& POL'Y REV. 63 (2001). This article is a reworked portion of an amicus brief authored by the Lambda Legal Defense Fund that argued that California's Unruh Civil Rights $\mathrm{Act}^{79}$ imposes an affirmative duty upon educational institutions to take steps to rectify

79. In 2001, the statute read: "All persons within the jurisdiction of this state are free and equal, and no matter what their sex, race, color, religion, ancestry, national origin, or disability are entitled to the full and equal accommodations, advantages, facilities, privileges, or services in all business establishments of every kind whatsoever." It has since been amended to include sexual orientation. See Civil Rights Act of 2005, 2005 Cal. Legis. Serv. 2777-78, $\$ 3$ (codified as amended at CAL CIV. CODE $\S$ 51 (West 2006)). 
educational environments that are hostile to certain minorities. The article also includes some statistics on hate crime that Lambda presented to the court.

Maggie J. Randall Robb, $A$ School's Duty to Protect Students From Peer Inflicted Abuse: Nabozny v. Podlesny, 92 F.3d 446 (7th Cir. 1996), 22 DAYTON L. REV. 317 (1997). In Nabozny, the Seventh Circuit found a violation of the plaintiff's equal protection rights, but held that his substantive due process rights had not been violated ${ }^{80}$ Analogizing to cases in which plaintiffs are in the custody of the state, ${ }^{81}$ this student piece argues that a special relationship between Nabozny and the state was created by the school's actions and policies, which limited Nabozny's ability to protect himself or flee his tormentors.

Joan E. Schaffer, Approaching the New Millennium with Mixed Blessings for Harassed Gay Students, 22 HARV. WOMEN's L.J. 159 (1999). The article focuses on the limitations of Title IX in protecting queer youth from hostile environment sexual harassment claims and contrasts those limitations with the potential to use recent decisions under Title VII as a way to expand Title IX. The article also examines the then-recent actions by the Department of Education's Office of Civil Rights, specifically the issuance of guidelines stating that sexual harassment directed at gay or lesbian students might constitute sexual harassment prohibited by Title IX.

Toni Wehman, Not Part of the Game Plan: School District Liability for the Creation of a Hostile Athletic Environment, 77 U. COLO. L. REV. 767 (2006). This piece explores the intersection of harassment based on sexual or gender stereotyping and that based on perceived sexual orientation. Arguing that these two different types of harassment are without distinction to the victim, the author urges that Title IX protections be expanded at least to the level provided by Title VII cases such as Price Waterhouse v. Hopkins. ${ }^{82}$ There is a useful discussion of harassment cases under multiple legal theories, as well as suggestions for educational guidelines to minimize such harassment.

Courtney Weiner, Sex Education: Recognizing Anti-Gay Harassment as Sex Discrimination Under Title VII and Title IX, 37 COLUM. HUM, RTS. L. REV. 189 (2005). This piece argues that while neither Title VII nor Title IX cover

80. Nabozny v. Podlesny, 92 F.3d 446, 460-61 (7th Cir. 1996).

81. Robb cites DeShaney v. Winnebago County Dep't of Soc. Services, 489 U.S. 189 (1989) (concluding that if injured child had been in custody of the state instead of the father, the state would be liable for injury); Youngberg v. Romeo, 457 U.S. 307 (1982) (finding that the state has an affirmative duty to protect those involuntarily committed to mental institutions); and Estelle v. Gamble, 429 U.S. 97 (1976) (finding that the state has an obligation to provide prisoners with medical care).

82. 490 U.S. 228 (1989) (equating sex stereotyping with impermissible gender discrimination). 
harassment based on sexual orientation, courts have begun to recognize and find actionable harassment based on the sexual stereotyping often used to justify sexual orientation discrimination. The author compares and contrasts the relative successes of cases involving same-sex and sexual orientation harassment under Title VII and Title IX.

\section{Freedom of Speech and Other Constitutional Issues Affecting Queer Kids in Schools}

Theresa J. Bryant, May We Teach Tolerance? Establishing the Parameters of Academic Freedom in Public Schools, 60 U. PITT. L. REV. 579 (1999). This article discusses Supreme Court precedents in school speech cases (involving both students and teachers), applies the holdings in those cases to ten particular examples of tolerance education, and analyzes whether the examples would be protected under the First Amendment. The examples range from discussing HIV in health class or discussing the sexuality of a historic figure to a teacher mentioning her partner in class or assigning a queer-themed book.

Patrick Henigan, Is Parental Authority Absolute? Public High Schools Which Provide Gay and Lesbian Youth Services Do Not Violate the Constitutional Childrearing Right of Parents, 62 BROOK. L. REV. 1261 (1996). This piece examines the viability of a parental suit against a school for providing queer youth services. The author suggests that such suits are often a successful tactic by groups opposing services to queer high school students because they effectively keep school officials from providing necessary information about health and sex to queer youth. The piece concludes that the limits of parental authority, the rights of individual students, the voluntary nature of the services the school provides, and the state's own parens patria interests create a defense to these lawsuits.

Lynn Mostoller, Freedom of Speech and Freedom from Student-on-Student Sexual Harassment in Public Schools: The Nexus Between Tinker v. Des Moines Independent Community School District and Davis v. Monroe County Board of Education, 33 N.M. L. REV. 533 (2004). This article seeks to reconcile the "only two federal cases to date" that address the potentially conflicting issues of student freedom of speech and student peer harassment. ${ }^{83}$ She concludes that well-drafted harassment polices that distinguish and limit only speech actively causing disruption or interference will be constitutional.

83. See Saxe v. State Coll. Area Sch. Dist., 240 F.3d 200 (3d Cir. 2001) (finding school district's anti-harassment policy unconstitutionally broad and in violation of a Christian student's right to speak out against homosexuality); Henkle v. Gregory, 150 F. Supp. 2d 1067 (D. Nev. 2001) (allowing student's claim that school officials had violated his First Amendment rights by ordering him not to disclose his sexual orientation to proceed). 
John A. Russ IV, Shall We Dance: Gay Equality and Religious Exemptions at Private California High School Proms, 42 N.Y.L. SCH. L. REV. 71 (1998). The piece discusses the clash between religious exemptions from general antidiscrimination laws and individual rights to expression and equal treatment. The author argues that the California Supreme Court's ruling in Smith v. Fair Employment \& Housing Commission, ${ }^{84}$ combined with general religious exemption doctrine provides substantial support for queer students suing to take same-sex dates to private school functions. ${ }^{85}$

Nancy Tenney, The Constitutional Imperative of Reality in Public School Curricula: Untruths About Homosexuality as a Violation of the First Amendment, 60 BROOK. L. REV. 1599 (1995). This article argues that attempts to require anti-gay content in school curricula violate student rights to receive information under the First Amendment.

\section{Gay/Straight Alliances and Other Queer Student Groups}

Brian Berkley, Making Gay Straight Alliance Student Groups Curriculum Related: A New Tactic for Schools Trying To Avoid the Equal Access Act, 61 WASH. \& LEE L. REV. 1847 (2004). This article explores the ability of a school to exert control over student access to gay/straight alliances (GSAs) under the Equal Access Act (EAA). ${ }^{86}$ The author argues that by making a GSA "curriculum-related," schools are able to require parental notification. The article provides background on the EAA and its application to GSAs in several federal court cases.

Susan Broberg, Gay/Straight Alliances and Other Controversial Student Groups: A New Test for the Equal Access Act, 1999 BYU EDUC. \& L.J. 87. This article, written before the settlement that ended the extended battle to keep GSAs out of Salt Lake City schools, discusses queer student use of the EAA to force the school to recognize their club. The piece provides insight into the background of East High Gay/Straight Alliance v. Board of Education, a longrunning and path-breaking court case. ${ }^{87}$

84. Smith v. Fair Employment \& Hous. Comm'n, 913 P.2d 909 (Cal. 1996) (finding a landlord's refusal to rent to an unmarried couple on religious grounds was not protected by the free exercise clauses of the state or federal constitutions).

85. There are also several law review articles that discuss this issue from a Canadian perspective. See infra Section VII.F.

86. 20 U.S.C. $\$ 4071(2006)$.

87. See, e.g., E. High Gay/Straight Alliance v. Bd. of Educ., 81 F. Supp. 2d 1186 (D. Utah 1999). The East High School GSA's battle with the Salt Lake City School Board was the first invocation of the EAA by a queer student group and resulted in a long legal battle that ended in a settlement in the students' favor. The battle and the settlement seemed to signal broader acceptance of GSAs in public 
Doni Gewirtzman, Comment, Make Your Own Kind Of Music: Queer Student Groups and the First Amendment, 86 CAL. L. REV. 1131 (1998). This comment focuses specifically on First Amendment issues raised by school boards banning queer student groups such as GSAs. The comment provides an overview of the Supreme Court's student speech decisions and their possible applications to queer student groups. The author suggests that the Court adopt an approach which inquires into the function of educational institutions and the nature of the relationship between regulation of speech and the mission of the educational institution.

Regina M. Grattan, It's Not Just for Religion Anymore: Expanding the Protections of the Equal Access Act to Gay, Lesbian, and Bisexual High School Students, 67 GEO. WASH. L. REV. 577 (1999). In the context of Utah's attempt to ban gay student clubs, this note examines the use of the federal Equal Access Act by queer students to prevent content-based discrimination against them. It analyses the use of the EAA by religious groups in schools and provides background on attempts by Utah state legislators to evade the EAA by crafting a statute specifically targeting queer students. ${ }^{88}$

Mathew Hilton, Options for Local School Districts Reviewing Local Governance and Moral Issues Raised by the Equal Access Act: The GayStraight Alliance in Utah, 1996 BYU EDUC. \& L.J. 1. This piece, written at the start of the Utah gay/straight alliance litigation, suggests that the school board might be successful if it argued that homosexuality was a dysfunction not to be encouraged or promoted by the formation of a GSA.

Ralph D. Mawdsley, The Equal Access Act and Public Schools: What are the Legal Issues Related to Recognizing Gay Student Groups?, 2001 BYU EDUC. \& L.J. 1. The article examines possible indicia of curriculum-relatedness of different school groups under the EAA using the Utah GSA case as an illustrative example.

Sarah Orman, "Being Gay in Lubbock:" The Equal Access Act in Caudillo, 17 HAstings WOMEN'S L.J. 227 (2006). This student note examines the

schools. See infra Sarah Orman, "Being Gay in Lubbock": The Equal Access Act in Caudillo, 17 HASTINGS WOMEN'S L.J. 227, 234 (2006).

88. UTAH CODE ANN. § 53A-3-419 (1997) (repealed 2007). While the act does not mention lesbian or gay students, state legislators were clear that it was specifically drafted to stop GSAs from forming in Utah schools. See Regina M. Grattan, It's Not Just for Religion Anymore: Expanding the Protections of the Equal Access Act to Gay, Lesbian, and Bisexual High School Students, 67 GEO. WASH. L. REV. 577, 587-91 (1999). 
Caudillo decision, ${ }^{89}$ focusing on the application of the subsections of the EAA that allow exclusions of student groups if they are disruptive. ${ }^{90}$ The note provides a historical context for the use of the EAA by GSAs and similar groups. It also provides extensive factual background on the participants in Caudillo.

Carolyn Pratt, Protecting the Marketplace of Ideas in the Classroom: Why the Equal Access Act and the First Amendment Require the Recognition of Gay/Straight Alliances in America's Public Schools, 5 FIRST AMEND. L. REV. 370 (2007). This student note tracks the growth of GSAs across the country and the strategies school districts have used in attempting to prohibit them. Much of the article contrasts arguments made by the school district in Caudillo with holdings in more recent cases that have declined to adopt Caudillo's reasoning. 91

Alice Riener, Comment, Pride and Prejudice: The First Amendment, the Equal Access Act, and the Legal Fight for Gay Student Groups in High Schools, 14 AM. U. J. GENDER SOC. POL'Y \& L. 613 (2006). This student comment discusses the Caudillo decision and argues that the school engaged in impermissible content and viewpoint discrimination when refusing to allow the student group to meet on campus. The piece examines both the student group's website and the school's abstinence-only policies in detail and analyses them under current First Amendment and EAA doctrine.

John A. Russ IV, Creating a Safe Space for Gay Youth: How the Supreme Court's Religious Access Cases Can Help Young Gay People Organize at Public Schools, 4 VA. J. SOC. POL'Y \& L. 545 (1997). Written before the first gay student group filed suit under the EAA, ${ }^{92}$ this student piece discusses the possibility that the EAA and court opinions allowing religious groups to use public school facilities can be successfully used to provide the same results to gay students.

89. Caudillo v. Lubbock Ind. Sch. Dist., 311 F. Supp. 2d 550 (N.D. Tex. 2004). This is one of the few cases in which a court has upheld a school or school district's refusal to allow a gay student group to form under the Equal Access Act. Most commentators suggest that the distinction in Caudillo was the student group's explicit goal of providing safe-sex education coupled with the school district's abstinence-only policy. Most GSA groups state their goals and objectives as promoting tolerance. At least one court has distinguished Caudillo on this ground. See Gay-Straight Alliance of Okeechobee High Sch. v. Sch. Bd. of Okeechobee County, 483 F. Supp. 2d 1224, 1229 (S.D. Fla. 2007).

90. The specific sections of the EAA discussed are 20 U.S.C. $\$ 4071$ (c), (f) (2000).

91. See supra note 89.

92. E. High Gay/Straight Alliance v. Bd. of Educ., 30 F. Supp. 2d 1356 (D. Utah 1998) [hereinafter East High $\Pi$. See supra note 87 and accompanying text. 
Eric W. Schulze, "Gay-Related" Student Groups and the Equal Access Act, 196 ED. LAW REP. 369 (2005). This is a very short piece summarizing gay student group use of the EAA. The piece moves through application of the EAA, starting with threshold issues such as whether or not a limited open forum has been created, to a discussion of the only successful attempt by a school board to restrict GSAs in Caudillo. ${ }^{93}$

\section{E. The Harvey Milk School and Other Schools Designed Specifically for Queer Students ${ }^{94}$}

Rebecca Bethard, Chalk Talk-New York's Harvey Milk School: A Viable Alternative, 33 J.L. \& EDUC. 417 (2004). This very short piece discusses the debate raised over the expansion and public funding of the Harvey Milk School. The article effectively summarizes the statistics and studies on the violence queer students face in the public school system. It also describes litigation attempting to close the school on the basis that it violates the constitutional rights of heterosexual students.

Kristina Brittenham, Equal Protection Theory and the Harvey Milk High School: Why Anti-Subordination Alone Is Not Enough, 45 B.C. L. REV. 869 (2004). While suggesting that the Harvey Milk High School would likely survive an equal protection challenge, the note argues that the school's voluntary segregation actually sends the message that hostility justifies segregation. The author equates supporting the voluntary segregation of Harvey Milk High School with the "Don't Ask, Don't Tell" policy. ${ }^{95}$ The piece argues that programs that provide safe and queer-sensitive educational opportunities in non-segregated settings will be more conducive to long-term protection of queer kids.

Nicolyn Harris \& Maurice R. Dyson, Safe Rules or Gays' Schools? The Dilemma of Sexual Orientation Segregation in Public Education, 7 U. PA. J. CONST. L. 183 (2005). In this wide-ranging essay on peer harassment of queer youth, Harris and Dyson examine the legal remedies and other mechanisms

93. For a discussion of Caudillo, see supra note 89 and accompanying text.

94. The Harvey Milk School was founded in 1985 by the Hetrick-Martin Institute to address the needs of queer or perceived-as-queer students. The original mission was to provide a safe haven from the violence and intolerance that the students faced in their traditional schools. Jesse Green, This School Is Out, N.Y. TIMES, Oct. 13, 1991, at 32. The school, though always accredited, is now administered by the New York City Department of Education and, in 2004, expanded from serving 50 students to serving a almost 170. Katherine Zoepf, Protests Mar Opening of Expanded Harvey Milk School, N.Y. TIMES, Sept. 9, 2003, at B3.

95. See Policy Concerning Homosexuality in the Armed Forces, 10 U.S.C. $\$ 654$ (1997). See also DOD Directive 1332.14.E3.A1.1.8.1.1 (1993) ("Sexual orientation is considered a personal and private matter and is not a bar to continued service, under this section, unless manifested by homosexual conduct."). 
available to address harassment, such as separate schools, the Rainbow Curriculum, and the "Safe School Programs." They conclude that separate schools for queer youth are not ideal and suggest that only supportive school environments that integrate queer kids can really induce long-term changes. However, they also recognize that there may be cases where the level of antigay harassment is so severe that separate schools are the only way to protect queer students.

Randy Hedlund, Segregation by any Other Name: Harvey Milk High School, 33 J.L. \& EDUC. 425 (2004). This short piece argues that by segregating queer students and using federal funds to do so, the Harvey Milk High School is in violation of Title IX of the Education Amendments of $1972 .{ }^{96}$ According to the article, this reinstitutes the "separate but equal" standard overruled in Brown v. Board of Education. ${ }^{97}$ The author contends that even though the school does not discriminate on the basis of sexuality, this "freedom of choice" plan is insufficient to prevent sexual segregation.

Kim Paula Kirkley, Don't Forget the Safety Net that All-Gay Schools Provide in Considering the Issues Raised by All-Female Public Education, 14 N.Y.L. SCH. J. HUM. RTS. 127 (1999). This piece documents some extreme examples of peer student harassment inflicted on queer youth such as beatings, burnings, rapes, and attempted murder. The author uses the example of the Harvey Milk School in New York to suggest that schools specifically for students targeted because of their perceived sexual orientation create a positive example for the use of all-female schools to deal with similar issues faced by girls in public education.

Erik K. Ludwig, Protecting Laws Designed To Remedy Anti-Gay Discrimination from Equal Protection Challenges: The Desirability of Rational Basis Scrutiny, 8 U. PA. J. CONST. L. 513 (2006). This student work discusses anti-gay challenges to legislation supportive or protective of gay rights. Using Harvey Milk High School as an example, the author argues that the gay rights movement's strategy to seek out suspect-class status now does more harm than good, in the wake of Supreme Court decisions barring moral disapproval as a rational reason for anti-gay legislation.

Thomas A. Mayes, Separate Public High Schools for Sexual Minority Students and the Limits of the Brown Analogy, 35 J.L. \& EDUC. 339 (2006). In

96. 20 U.S.C. $\S 1681$ (a) (2000).

97. Brown v. Bd. of Educ. of Topeka, 347 U.S. 483 (1954) (holding that segregated schools based on race violate the Equal Protection Clause of the Fourteenth Amendment). 
a response to the Hedlund piece above, ${ }^{98}$ Mayes argues that providing separate schools for queer students for their own protection would pass a rational basis test and that the Brown v. Board of Education analogy is inapt for other, deeper reasons: returning queer students to unsafe schools where they would be unable or unlikely to seek redress would "us[e] a law designed to achieve equality to further entrench inequality and dominance," and treating relevant differences the same way ignores students' real needs. ${ }^{99}$

Louis P. Nappen, Why Segregated Schools for Gay Students May Pass a 'Separate But Equal' Analysis But Fail Other Issues and Concerns, 12 WM. \& MARY J. WOMEN \& L. 101 (2005). More essay than analysis, the piece argues that schools directed primarily at queer students may be legal but relegate those students to a "separate but equal" status. The author uses a wide range of supporting references from pundits to law reviews to newspaper articles that would be useful in researching the controversy surrounding the expansion of the Harvey Milk School in New York City.

\section{F. Canadian Articles Addressing Queer Student Issues}

William Black, Grading Human Rights in the Schoolyard: Jubran v. Board of Trustees, 36 U.B.C. L. REV. 45 (2003). This short work discusses the failure of the British Columbia Supreme Court to apply the Human Rights Code to a "straight" student who was harassed by other students. ${ }^{100}$ Harassers knew the student was not gay, but used anti-gay slurs against him. The piece argues that anti-gay slurs harm other gay and lesbian students hearing the harassment and that that alone should have supported a finding that the Human Rights Code was violated.

Bruce MacDougall, Silence in the Classroom: Limits on Homosexual Expression and Visibility in Education and the Privileging of Homophobic Religious Ideology, 61 SASK. L. REV. 41 (1998). MacDougall describes the Canadian judiciary's tradition of supporting religious interests over the interests of sexual minorities. He then discusses how that difference stops positive messages about gay and lesbian rights from reaching Canadian youth.

Bruce MacDougall, The Separation of Church and Date: Destabilizing Traditional Religion-Based Legal Norms on Sexuality, 36 U.B.C. L. REV. 1

98. Randy Hedlund, Segregation by Any Other Name: Harvey Milk High School, 33 J.L. \& EDUC. 425 (2004).

99. Thomas A. Mayes, Separate Public High Schools for Sexual Minority Students and the Limits of the Brown Analogy, 35 J.L. \& EDUC. 339, 343-44, 345 (2006).

100. Jubran v. Bd. of Trustees, [2002] 42 C.H.R.R. D/273 (Can.). 
(2003). This article discusses Hall v. Powers, ${ }^{101}$ the Canadian "gay prom" case, which allowed a gay student to take a same-sex date to a dance at his private, religious high school. While Hall and other recent Canadian decisions suggest a re-evaluation of the importance of sexual orientation equality in education or school contexts, the cases are not argued on the basis of supporting student sexuality. The author suggests that courts and society still refuse to see children as potential sexual beings and this refusal limits the support queer youth find in educational settings.

Zoe Oxaal, Second-Guessing the Bishop: Section 93, the Charter, and the "Religious Governmental Actor" in the Gay Prom Date Case, 66 SASK. L. REV. 455 (2003). This student article examines Hall v. Powers, and discusses the competition between religious and secular individual rights under the Canadian Charter.

Elichai Shaffir, Dancing Like It's 1867: How Can Religious Intolerance Be Supreme Law in 2006?, 16 EDUC. \& L.J. 1 (2006). Rooting itself in Hall v. Powers, this piece argues that as a public policy basis, religious institutions should not be allowed to discriminate on the basis of sexual orientation, even in light of Section 93 of the Constitution Act of 1867. For those unfamiliar with Canadian human rights law, Shaffir provides a useful outline of the conflict between Canada's Charter Rights and the rights given to religious schools through Section 93.

\section{ACCESS TO HEALTHCARE}

Access to healthcare is a vital issue, and one where queer youth have often been overlooked. The articles that follow are illustrative of the legal obstacles minors must overcome in seeking any health care without parental consent or without the medical provider notifying a parent. This occurs most often in cases involving a minor's potential sexuality, when, for example, minors attempt to obtain abortions, contraception, and treatment or testing for HIV/AIDS or other sexually transmitted diseases.

While not all HIV-positive youth are queer, there is a large sub-population of queer youth that is at risk of coming into contact with sexually transmitted diseases. ${ }^{102}$ Thus several recent articles concerning HIV/AIDS and adolescents are provided. Articles dealing with GID or transgender minors' access to healthcare are collected in Part V of this Bibliography.

101. [2002] 213 D.L.R. 308 (Can.).

102. See RAY, supra page 457. 
William Adams, 'But Do You Have To Tell My Parents?': The Dilemma for Minors Seeking HIV-Testing and Treatment, 27 J. MARSHALL L. REV. 493 (1994). This article discusses evolving standards regarding minors' right to consent to healthcare and research into the cognitive abilities of minors to make reasoned decisions. It specifically addresses how the fear of revealing their sexual orientation creates additional obstacles for queer youth seeking testing or treatment for HIV.

Emily A. Bishop, A Child's Expertise: Establishing Statutory Protection for Intersexed Children who Reject Their Gender of Assignment, 82 N.Y.U. L. REV. 531 (2007). In general, articles discussing the legal issues surrounding intersex children and their medical treatment have not been annotated in this bibliography. ${ }^{103}$ This work specifically addresses the issue of adolescents seeking to obtain medical care to transition from one gender to another after being assigned a gender by their parents and the medical establishment during infancy. The student note suggests a statutory framework that would permit a minor to pursue this goal even in the face of parental opposition.

Abigail English \& Madlyn Morreale, A Legal and Policy Framework for Adolescent Health Care: Past, Present and Future, 1 Hous. J. HEALTH L. \& POL'Y 63 (2001). English and Morreale include gay, lesbian, and bisexual adolescents in the definition of special populations that are more likely to need intensive health services and to have greater difficulty accessing traditional sources of care than other adolescents. The article also provides an overview of current legal frameworks for youth seeking medical care.

Christopher Garfield, Enabling Responsibility: Adolescent Autonomy and the Teen HIV Crisis in the United States, 8 J. MED. \& L. 87 (2003-2004). The author argues that the law's view of minors as incompetent to give informed consent to HIV testing hampers the medical system's ability to fight the spread of HIV/AIDS. The piece proposes national legislation that would allow minors to consent to HIV testing and treatment without parental consent or notification.

Rhonda Gay Hartman, Aids and Adolescents, 7 J. HeAlth CARE L. \& POL'Y 280 (2004). The author argues that the current state of the law, which requires parental consent and notification prior to testing and treatment of

103. Most of the medical treatment or activity that gives rise to potential litigation or ethical issues around intersex persons takes place in infancy. It is a growing area of legal academic study. See Symposium, Intersex Education, Advocacy, \& the Law, 12 CARDOzo J.L. \& GENDER 1 (2005). For an overview of the many issues involved in the treatment of intersexed infants, see Hazel Glenn Beh \& Milton Diamond, An Emerging Ethical and Medical Dilemma: Should Physicians Perform Sex Assignment Surgery on Infants with Ambiguous Genitalia?, 7 MICH. J. GENDER \& L. 1 (2000). 
minors for HIV, is in large part responsible for the looming adolescent HIV crisis. The article proposes that U.S. lawmakers look to the laws of other nations, which provide adolescent medical autonomy, and begin to build a statutory framework specific to HIV/AIDS legislation that strikes a balance between parental authority and adolescent autonomy.

Rhonda Gay Hartman, Coming of Age: Devising Legislation for Adolescent Medical Decision-Making, 28 AM. J.L. \& MED. 409 (2002). This is an overview of state statutes and cases concerning the parameters of adolescent medical decision-making and parental consent. The article argues that the dearth of scientific research into adolescent decision-making capacity is problematic. The author argues that additional research could serve as a foundation for expanding legislation and case law in the area of adolescent decision-making.

David R. Katner, The Ethical Dilemma Awaiting Counsel who Represent Adolescents with HIV/AIDS: Criminal Law and Tort Suits Pressure Counsel To Breach the Confidentiality of the Clients' Medical Status, 70 TUL. L. REV. 2311 (1996). Although the essay is focused on possible ethical dilemmas presented by representing HIV-positive youth, the piece also provides a discussion of HIV-positive youth and their privacy rights.

Roger J.R. Levesque, The Peculiar Place of Adolescents in the HIV-AIDS Epidemic: Unusual Progress \& Usual Inadequacies in "Adolescent Jurisprudence," 27 LOY. U. CHI. L.J. 237 (1996). The article discusses the general requirement that children have parental consent prior to receiving health care and notes that states, in response to the adolescent HIV crisis, are increasingly exempting HIV testing from these requirements.

\section{IMMIGRATION}

As in other social-legal arenas, queer youth attempting to gain permanent residency or asylum in the United States face challenging odds against success, based on the combination of age and queer status. As with queer adults, queer youth flee their home countries because of persecution based on sexual orientation or gender identity. ${ }^{104}$ However, children face detention and an "inherently coercive" U.S. immigration system if they come as an

104. See Hernandez-Montiel v. INS, 225 F.3d 1084 (9th Cir. 2000) (granting asylum to a fifteenyear old "gay man with female sexual identity"); Pitcherskaia v. INS, 118 F.3d 641 (9th Cir. 1997) (discussing the asylum claim of an adult lesbian who, as a teen and young adult in Russia, was forced to undergo conversion therapy and institutionalization); Pamela Constable, Persecuted Gays Seek Refuge in the U.S.: Foreigners' Abuse Increasingly Seen as Grounds for Asylum, WASH. POST, July 10, 2007, at A6. 
unaccompanied minor. ${ }^{105}$ In addition, it is not unusual for families who are in the process of immigrating to disown and refuse to assist a child who has announced a minority sexual orientation or has suddenly been perceived to be queer, ${ }^{106}$ effectively ending that child's chance of immigrating lawfully.

The Hazeldean and Singla article below is the only article that specifically addresses queer youth and immigration. Two other immigration articles discuss queer youth in some limited way. Therefore, also included are recent works ${ }^{107}$ that address immigration of minors and juveniles in general and of queer adults. While work specifically on this point is limited, organizations and agencies that work on issues affecting alien children in the United States are recognizing that sexuality is a component of clients' lives that needs to be addressed. ${ }^{108}$

Susan Hazeldean \& Pradeep Singla, Out in the Cold: The Challenges of Representing Immigrant Lesbian, Gay, Bisexual, and Transgender Youth, 7 BENDER'S IMMIGR. BULL. 642 (2002), available at http://www.urbanjustice.org/pdf/publications/lesbianandgay/OutintheCold.pdf. This short article describes the common problems queer youth face in legalizing their immigration status. It focuses on the additional terrors immigrant queer youth face, including deportation, when they come out and their families reject them. It is one of the only articles in this collection that discusses representing queer youth in immigration proceedings. It outlines three distinct legal strategies that may be useful for queer youth seeking permanent residency or citizenship without the assistance of family.

Victoria Neilson \& Aaron Morris, The Gay Bar: The Effect of the OneYear Filing Deadline on Lesbian, Gay, Bisexual, Transgender, and HIVPositive Foreign Nationals Seeking Asylum or Withholding of Removal, 8 N.Y. CITY L. REV. 233 (2005). This one of the few articles that mention queer youth and immigration. It indicates that they "may be unable to pursue an asylum

105. Perez-Funez v. Dist. Dir., INS, 619 F. Supp. 656, 663 (C.D. Cal. 1985) (finding the "processing environment" of unaccompanied minors "inherently coercive"); Georgopoulous, infra page 492 (discussing the conditions faced by asylum-seeking unaccompanied minors).

106. See Hazeldean \& Singla, infra page 491 .

107. Works published after 2003 were selected in part to reflect the changes in immigration and asylum law since September 11,2001 , and to provide the broadest collection of cited caselaw within the articles.

108. American Bar association, Standards for the Custody, Placement and Care; LEGAL REPRESENTATION; AND ADJUDICATION OF UNACCOMPANIED ALIEN CHILDREN IN THE UNITED STATES 9 (2004), available at http://www.abanet.org/publicserv/immigration/ Immigrant_Childrens_Standards.pdf (suggesting a rule requiring the custodial agency to preserve a child's sexual identity); NATIONAL IMMIGRANT JUSTICE CENTER, WINNING ASYLUM, WITHHOLDING AND CAT CASES BASEd ON SEXUAL ORIENTATION, TRANSGENDER IDENTITY AND/OR HIV-POSITIVE STATUS 40 (2006), available at http:/www.immigrantjustice.org/documents/NAPSOManualJune2006_000.pdf (indicating that LGBT youth may face extraordinary circumstances excusing them from meeting deadlines if they have been unable to pursue their asylum claim because of fear of their family). 
claim based on their sexual orientation or gender identity until . . they are no longer living with potentially hostile family members."

Victoria Neilson, Homosexual or Female?: Applying Gender-Based Asylum Jurisprudence to Lesbian Asylum Claims, 16 STAN. L. \& POL'Y REV. 417 (2005). The article focuses on the difficulties lesbians have in proving persecution because the harms they are fleeing often occur in a private realm with attendant difficulties in proof. Neilson suggests that lesbian asylum cases should be categorized neither as purely sexual orientation cases nor as gender cases but should be seen "to lie at the intersection of both categories." 110 She illustrates her thesis with the hypothetical example of a twenty-three year-old lesbian who is beaten and raped by her family when her lesbianism is discovered, and who then flees to the United States seeking asylum.

\section{Additional Immigration Articles}

Areti Georgopoulous, Beyond the Reach of Juvenile Justice: The Crisis of Unaccompanied Immigrant Children Detained by the United States, 23 LAW \& INEQ. 117 (2005). This article discusses the failure of the INS to comply with a settlement agreement meant to address problems in its treatment of unaccompanied minors. After analyzing the proposed Unaccompanied Alien Child Protection Act (UACPA), ${ }^{11}$ the author finds it flawed and suggests alternative model legislation.

Dane Holbrook, Protecting Immigrant Child Victims of Domestic Violence Through U.S. Asylum Law, 12 KAN. J.L. \& PUB. POL'Y 311 (2003). This article outlines statutes and regulations related to child abuse and asylum law. It also cites several successful cases where children were granted asylum based on their fear of domestic violence in their countries of origin.

Joseph Landau, "Soft Immutability" and "Imputed Gay Identity": Recent Developments in Transgender and Sexual-Orientation-Based Asylum Law, 32 FORDHAM URB. L.J. 237 (2005). This piece provides a historic overview of queer asylum law cases, and then discusses two cases where transgendered

109. Victoria Neilson \& Aaron Morris, The Gay Bar: The Effect of the One-Year Filing Deadline on Lesbian, Gay, Bisexual, Transgender, and HIV-Positive Foreign Nationals Seeking Asylum or Withholding of Removal, 8 N.Y. CrTY L. REV. 233, 271 (2005).

110. Victoria Neilson, Homosexual or Female?: Applying Gender-Based Asylum Jurisprudence to Lesbian Asylum Claims, 16 STAN. L. \& POL'Y REV. 417, 426 (2005).

111. Legislation proposed by Sen. Diane Feinstein, S. 1129, 108th Cong. (2003) 
males were granted asylum. ${ }^{112}$ It also discusses the potential litigation strategies now available to queer asylum seekers.

Deborah A. Morgan, Not Gay Enough for the Government: Racial and Sexual Sterotypes in Sexual Orientation Asylum Cases, 15 LAW \& SEXUALITY 135 (2006). This student piece argues that stereotypes of homosexuality pervade the asylum process. Stereotypes force aliens seeking protection based on fear of sexual identity persecution to conform to American concepts of what it means to be gay. This creates a situation where judges are evaluating asylum claims not based on the actual persecution but on the judge's own perceptions or stereotypes of sexuality. Morgan uses the example of a judge denying asylum in the mistaken belief that if an asylum seeker could pass as straight in the United States they could successfully do so in their home country.

Laura Yoder Nafzieger, Protection or Persecution?: The Detention of Unaccompanied Immigrant Children in the United States, 28 HAMLINE J. PUB. L. \& POL'Y 357 (2006). The author argues that while there has been positive movement by the Department of Homeland Security in addressing the problems of detention of unaccompanied minors, much more needs to be done. The piece provides background on legacy INS settlement agreements and the Unaccompanied Alien Child Protection Act, ${ }^{113}$ and compares the U.S. system to those of Australia and Canada.

\section{CONCLUSION}

The burgeoning legal material on queer youth is a testament to both the difficulties this at-risk population faces and the resources available to ensure that queer youth survive and flourish. New scholarship, advocacy, policy statements, and legislative reforms will continue to build on the foundations contained in the articles collected in this annotated bibliography. In addition, the reports, studies, and briefings listed will provide the statistics and personal narratives necessary to support the difficult work of creating a new environment in which a child's queerness is no longer seen as a reason for abuse.

112. Reyes-Reyes v. Ashcroft, 384 F.3d 782 (9th Cir. 2004); Hernandez-Montiel v. INS, 225 F.3d 1084 (9th Cir. 2000).

113. See supra text accompanying note 111 . 
